\title{
Kształtowanie sieci młynów wodnych na przykładzie powiatu konińskiego (ok. 1300-1550)'
}

\author{
Tomasz Związek
}

\section{Podstawa źródłowa i główne problemy badawcze}

Kwestie gospodarcze historii średniowiecza zajmowały badaczy od dawna. W polskiej historiografii tematyka ta rozwinęła się w znacznym stopniu po drugiej wojnie światowej w związku $\mathrm{z}$ badaniami tzw. historii kultury materialnej skupiającej się na zjawiskach opisujących zajęcia zawodowe ludzi minionych epok. Wtedy to zaczęto badać poszczególne rodzaje rzemiosł i procesów gospodarczych odpowiadających za ich rozwój lub stagnację. Stosunkowo niewiele miejsca zajmowały badania nad średniowiecznym młynarstwem na ziemiach polskich, które skupiały się w głównej mierze na: 1 . początkach tej gałęzi przemysłu na ziemiach polskich; 2. gospodarczym funkcjonowaniu zakładów przemiałowych w strukturze ekonomicznej mikroregionów; 3. wydajności młynów i wiatraków; 4. stosunku władzy świeckiej lub duchownej do przemiału i obiektów go prowadzących.

Wśród prac poświęconych tej tematyce nie udało się odnaleźć badań, które w jasny sposób omawiałyby mechanizmy wpływające na kształtowanie sieci młynów wodnych (i wiatraków) w przestrzeni ekonomicznej średniowiecza i wczesnej nowożytności na ziemiach

\footnotetext{
${ }^{1}$ Serdecznie dziękuję mgr. Jerzemu Łojce z Konina i mgr. Tomaszowi Gidaszewskiemu z Poznania za udostępnienie materiałów źródłowych do badań nad siecią młynów wodnych w powiecie konińskim. Osobne podziękowania należą się także dr. Pawłowi Dębińskiemu, bez którego trafnych uwag i ogromnej życzliwości przeanalizowanie całości konińskich wypisów z kartoteki Stownika Historyczno-Geograficznego w Poznaniu byłoby bardzo trudne.

${ }^{2}$ Z. Podwińska, Rozmieszczenie wodnych młynów zbożowych w Małopolsce w XV wieku, „Kwartalnik Historii Kultury Materialnej”, 18 (3), 1970, s. 373-376. 0 bardzo poważnych problemach związanych z XIX-wieczną edycją krakowskiej księgi uposażeń zob. M.D. Kowalski, Dzieje autografu katedralno-kolegiackiej części "Liber beneficiorum diocesis Cracoviensis" Jana Długosza, „Studia Źródłoznawcze”, 46, 2009, S. 83-84.

${ }^{3}$ R. Kubicki, Młynarstwo w państwie zakonu krzyżackiego w Prusach w XIII-XV wieku (do 1454 r.), Gdańsk 2012, s. 289-341; tenże, Wia-
}

polskich. Pewną próbę przedstawienia tego zjawiska podjęła w latach 70 . ubiegłego stulecia Zofia Podwińska, analizująca to zagadnienie na podstawie Długoszowego Liber beneficiorum i wydanego do tego czasu małopolskiego materiału dyplomatycznego ${ }^{2}$. Całkiem niedawno podobną tematyką zajął się też Rafał Kubicki, który w swojej książce zwrócił uwagę na sprawę rekonstrukcji sieci młynów wodnych i wiatraków na terenie państwa krzyżackiego ${ }^{3}$. Zagadnienie to ukazywano też w polskiej historiografii jako część analiz związanych z funkcjonowaniem średniowiecznych miast i ich gospodarką wodną czy szczegółowymi studiami nad dobrami królewskimi ${ }^{4}$. Warto także wspomnieć o próbach podejmowanych przez geografów, którzy przyczynili się nie tylko do powstania Atlasu rozmieszczenia mtynów wodnych notującego obiekty od końca XVIII do połowy XX w. (głównie w oparciu o materiały kartograficzne), ale przygotowali także interesujące studia poświęcone przyrodniczym uwarunkowaniom sprzyjającym powstawaniu młynów wodnych ${ }^{5}$. Niestety tematyka ta nie interesowała $w$ większym stopniu polskich archeologów, którzy nie

traki na Zuławach w pierwszej połowie XV wieku, „Roczniki Dziejów Społecznych i Gospodarczych", 72, 2012, s. 45-69; tenże, Sieć młynów wodnych w dobrach klasztornych na Pomorzu Wschodnim w XIII-XVI w., „Hereditas Monasteriorum”, 2, 2013, s. 35-56.

4 Zob. przykładowo prace: A. Wawrzyńczyk, Gospodarstwo chłopskie w dobrach królewskich na Mazowszu w XVI i na początku XVII w. Warszawa 1962; A. Wyczański, Studia nad gospodarką starostwa korczyńskiego 1500-1660, Warszawa 1964; U. Sowina, Woda i ludzie w mieście późnośredniowiecznym i wczesnonowożytnym. Ziemie polskie z Europą w tle, Warszawa 2009; K. Nabiałek, Starostwo olsztyńskie od XIV do połowy XVII wieku, Kraków 2012.

5 J. Gołaski, Atlas rozmieszczenia młynów wodnych w dorzeczach Warty, Brdy i części Baryczy w okresie 1790-1960, cz. 1-5, Poznań 1980-2006; Z. Podgórski, Wpływ budowy i funkcjonowania młynów wodnych na rzeźbę terenu i wody powierzchniowe Pojezierza Chetmińskiego i przyległych części dolin Wisty i Drwęcy, Toruń 2004; 
prowadzili ewidencji pozostałości po obiektach przemiałowych w ramach Archeologicznego Zdjęcia Polski i poprzestali na opublikowaniu kilku dosyć wyrywkowych wyników badań wykopaliskowych, które tylko w niewielkim stopniu pomagają $\mathrm{w}$ całościowych studiach nad rozwojem sieci młynów wodnych i wiatraków ${ }^{6}$. Także literatura obcojęzyczna, do której udało się dotrzeć, nie tyle analizowała mechanizmy kształtowania sieci młyńskiej, co raczej rekonstruowała ją na dany moment dziejowy lub w okresie kilkuset lat ${ }^{7}$.

Głównym celem prezentowanego artykułu jest próba opisania zjawiska kształtowania sieci młynów wodnych $\mathrm{w}$ późnym średniowieczu i wczesnej nowożytności. Badaniem objęto nie tyle same obiekty przemiałowe, zarówno młyny wodne, jak i wiatraki, co raczej procesy, odpowiadające za rozwój lub regres ich liczby w ciągu kolejnych wieków ${ }^{8}$. Zrezygnowano całkowicie $\mathrm{z}$ analizy źródeł dokumentowych wcześniejszych niż wiek XIV. Wynika to nie tylko z powodu ich ograniczonego zasobu, ale także z faktu, że - jak pokazał to tekst Karola Buczka - jest to materiał wymagający całkowicie osobnego opracowania i postawienia zupełnie innych pytań badawczych w skali całego państwa wczesnopiastowskiego ${ }^{9}$, a nie jednego, dosyć ograniczonego terytorium.

Całość analizy została przeprowadzona dla terenów dawnego powiatu konińskiego. Wy-

D. Brykała, Rekonstrukcja retencji zbiornikowej zlewni Skrwy Lewej w ciagu ostatnich 200 lat, „Przegląd Geograficzny”, 71 (1), 2005, s. 69-89; A. Kaniecki, A. Woźniak, M. Kornaś, Wykorzystanie wód dla potrzeb mfynarskich na obszarze międzyrzecza Warty i Prosny w XVI wieku, „Przegląd Geofizyczny”, 57 (3-4), 2012, s. 379-391.

6 K. Fokt, Późnośredniowieczne osadnictwo wiejskie na Dolnym Śląsku w świetle badań archeologicznych, Kraków 2012, s. 189.

$7 \mathrm{~J}$. Langdon, Mills in the Medieval Economy. England 1300-1540, Oxford 2004; N. Brady, Mills in Medieval Ireland: Looking Beyond Design, w: Wind \& Water in the Middle Ages: Fluid Technologies from Antiquity to the Renaissance, ed. S.A. Walton, Tempe 2006, s. 39-68; C.H. Berman, Southern French Cistercian Water Mills, „International Molinology", 85, 2012, s. 8-13.

8 Szerszy spis literatury dotyczącej młynarstwa zob.: U. Sowina, Woda i ludzie, s. 56; T. Związek, Testament młynarza z Koła. Przyczynek do badań nad późnośredniowiecznym młynarstwem na ziemiach polskich, „Średniowiecze Polskie i Powszechne”, 5 (9), 2013, s. 154-155.

9 K. Buczek, Z dziejów młynarstwa w Polsce średniowiecznej, „Studia Historyczne", 12 (1), 1969, s. 17-51. bór ten wynikał nie tylko z wcześniejszych zainteresowań autora ${ }^{10}$, ale także z zachowanej podstawy źródłowej. Chodzi tutaj o rejestry podatkowe z lat 1507-1510 ${ }^{11}$. Chociaż obejmują one również dwa sąsiednie powiaty (pyzdrski i kaliski), to ze względu na liczbę obiektów, a także bogaty zasób źródeł późnośredniowiecznych zdecydowano się opisać je w osobnym tekście. Warto także wspomnieć, że zasięg terytorialny opracowania jest związany z aktualnie prowadzonymi badaniami w Zakładzie Atlasu Historycznego (Instytut Historii im. Tadeusza Manteuffla PAN) nad mapą Wielkopolski w drugiej połowie XVI w. i wynikającą z tego stosunkowo łatwą dostępnością materiałów porównawczych z epoki nowożytnej ${ }^{12}$.

W trakcie prac korzystano z dokumentów pochodzących z Kodeksu dyplomatycznego Wielkopolski (tomy 2-11) i wydawnictw, takich jak Teki Dworzaczka ${ }^{13}$, Lustracja województw wielkopolskich $i$ kujawskich ${ }^{14}$, Lustracje $i$ inwentarze dóbr królewskich powiatu konińskie$g 0^{15}$, inwentarz dóbr biskupstwa lubuskiego z 1405 r. $^{16}$ i Liber beneficiorum ${ }^{17}$ Jana Łaskiego. Głównym masowym źródłem, z którego czerpano informacje o obiektach przemiałowych i które służyło do niezbędnych porównań, były jednak XVI-wieczne rejestry poboru nadzwy-

${ }^{10}$ T. Związek, Testament młynarza, passim.

11 Tenże, Najstarszy rejestr poboru nadzwyczajnego i szosu z 1507 roku z terenów powiatu konińskiego, „Rocznik Koniński”, 18, 2013 [wyd. 2014], s. 173-179.

12 Zob. tekst M. Gochny, Elektroniczna edycja rejestrów poborowych województwa kaliskiego z drugiej połowy XVI w. zamieszczony w niniejszym tomie „Studia Geohistorica”.

${ }^{13}$ Kodeks dyplomatyczny Wielkopolski, t. 2-11, red. I. Zakrzewski, A. Gąsiorowski, T. Jasiński i in., Poznań 1878-1999 [dalej: KDW]; Teki Dworzaczka. Materiały historyczno-genealogiczne do dziejów szlachty wielkopolskiej XV-XX wieku (http://teki.bkpan.poznan.pl/, dostęp: 28.08.2013) [dalej: TD].

14 Lustracja województw wielkopolskich i kujawskich 1564-1565, cz. 1-2, wyd. A. Tomczak, C. Ohryzko-Włodarska, J. Włodarczyk, Bydgoszcz 1961-1963.

15 Lustracje $i$ inwentarze dóbr królewskich powiatu konińskiego z XVI-XVIII wieku. Część 1: lata 1511-1559, wyd. P. Dembiński, A. Nowak, „Rocznik Koniński”, 13, 1999, s. 115-143. Odpowiednie lata tego wydawnictwa dalej kolejno jako: Lustracja 1511 i Lustracja 1559.

16 Das Lebuser Stiftsregister von 1405, hrsg. H. Ludat, Wiesbaden 1965 [dalej: Leb. Stiftsreg.].

17 Joannis de Lasco liber beneficiorum, wyd. J. Łukowski, t. 1-2, Gniezno 1880-1881. 
czajnego $^{18}$. Dane uzupełniano także za pomocą materiałów dotąd nieopublikowanych lub wydanych częściowo. Mam tu na myśli: Polonia Maior Fontes ${ }^{19}$, Najstarsza ksiege ziemska koniñska (1394-1416) ${ }^{20}$ i wypisy z ksiag ziemskich oraz grodzkich pochodzące z kartoteki Pracowni Słownika Historyczno-Geograficznego Wielkopolski IH PAN w Poznaniu ${ }^{21}$. Nieocenioną pomoc przy dokonywaniu szerszych analiz stanowity wydane do tej pory konstytucje sejmowe ${ }^{22}$.

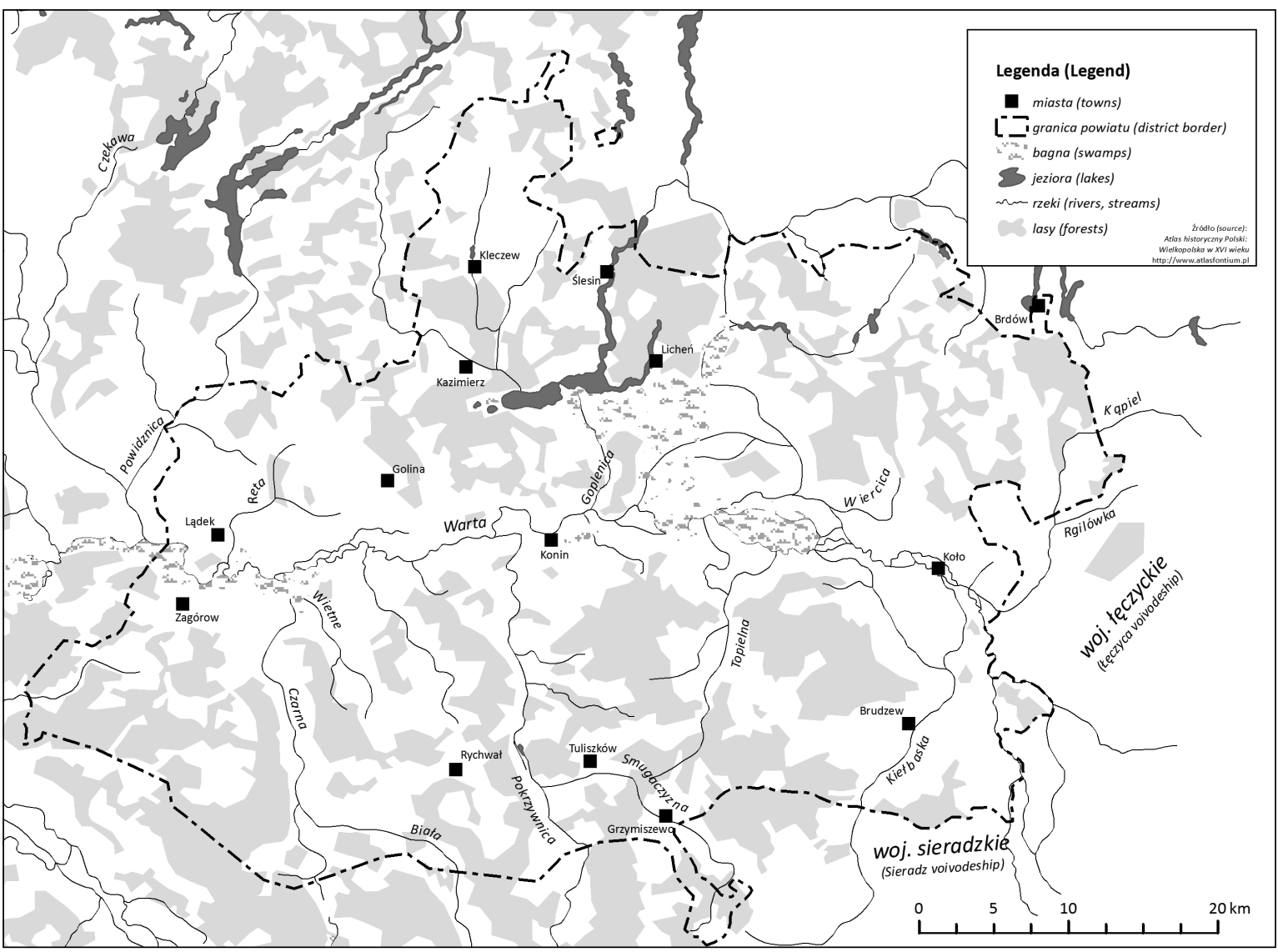

Mapa 1. Sieć rzeczna powiatu konińskiego w XVI w.

18 Wszystkie spisy podatkowe znajdują się w pierwszym oddziale Archiwum Skarbu Koronnego [dalej: ASK]. Szerzej o tym typie źródeł zob.: I. Gieysztorowa, A. Zaboklicka, Rejestry poborowe Mazowsza XVI w., „Kwartalnik Historii Kultury Materialnej”, 3, 1955, s. 338-355; K. Górska, Przyczynek do krytyki rejestrów poborowych z XVI w., ,Studia Źródłoznawcze", 1, 1957, s. 185-190; I. Gieysztorowa, Źródła i szacunki w badaniach osadnictwa i demografii Polski XVI i XVII w., „Kwartalnik Historii Kultury Materialnej”, 10, 1962, s. 576-584; P. Szafran, Inwentarze czy rejestry poborowe, ,Zapiski Historyczne”, 21 (1), 1966, s. 53-69; I. Gieysztorowa, Źródła pisane, w: Mazowsze w drugiej połowie XVI w., t. 2, red. W. Pałucki, Warszawa 1973, s. 17-22 (Atlas historyczny Polski. Mapy szczegółowe XVI wieku, 7). Całość informacji na temat rejestrów skarbowych zebrana została ostatnio w: K. Chłapowski, Written sources, w: Historical Atlas of Poland in the $2^{\text {nd }}$ half of the $16^{\text {th }}$ century. Voivodeships of Cracow,
Sandomierz, Lublin, Sieradz, Łęczyca, Rawa, Płock and Mazovia, ed. M. Stoń, vol. 2, Frankfurt a. Main-Berlin-Bern 2014, s. 47-61.

19 Polonia Maior Fontes, oprac. J. Łojko. Baza danych dostępna w Bibliotece Miejskiej w Koninie.

20 Najstarsza księga ziemska konińska (1394-1416), oprac. T. Gidaszewski [rkps w Pracowni Stownika Historyczno-Geograficznego Wielkopolski, Poznań].

${ }^{21}$ Główna zaleta tych wypisów polega obecnie na tym, że w kartotece znajdują się fiszki pochodzące z ksiąg sądowych powiatu poznańskiego, w których umieszczano transakcje potwierdzane przez starostę generalnego Wielkopolski. Dotarcie do tych danych w ramach osobnej kwerendy ksiąg poznańskich byłoby w pojedynkę zadaniem bardzo trudnym.

22 Volumina Legum, t. 1-2, Petersburg 1859 [dalej: VL]; Volumina Constitutionum, t. 1-2, Warszawa 1996-2005. 
Podstawę kartograficzną były zaś mapy opracowane przez Wojskowy Instytut Geograficzny (WIG) w skali 1:100 $000^{23}$ i Special Karte von Suedpreussen mit allerhoechster Erlaubniss... ${ }^{24}$ z 1802 r. autorstwa Davida Gilly'ego. Bardzo ostrożnie korzystano z Mappy szczegulney województwa kaliskiego zrządzoney z innych wielu mapp mieyscowych tak dawniey iak i pozney odrysowanych tudzież goscincowich y niewatpliwych wiadomości... autorstwa Karola Perthéesa ${ }^{25}$.

Dla zachowania porządku związanego z nazewnictwem brzmienie nazw miejscowych pochodzących z terenów dawnego województwa kaliskiego podawano w formie XVI-wiecznej, ustalanej na podstawie materiałów opracowywanych przez zespół Atlasu historycznego Pol$s k i^{26}$. W celu jaśniejszego wywodu umieszczono także mapę przedstawiającą główne rzeki i strumienie analizowanego terytorium oraz szereg dodatkowych planów.

\section{Trudności metodologiczne w badaniach nad siecią młynów wodnych}

$\mathrm{Na}$ pierwszy rzut oka wydaje się, że obliczenie ogólnej liczby młynów wodnych na terytorium powiatu, województwa albo państwa będzie zadaniem stosunkowo prostym, bo przecież opartym na najbardziej podstawowej operacji matematycznej. Jest to jednak założenie pozorne i zwodnicze. Wraz z postępem lat sytuacja młynów wodnych zmieniała się, a liczba obiektów była w ciągłym ruchu; niektóre z nich były budowane lub remontowane,

\footnotetext{
23 B. Krassowski, Polska kartografia wojskowa w latach 1918-1945, Warszawa 1974, s. 135-177. Adres internetowy archiwum map: http://polski.mapywig.org/news.php, dostęp: 28.08.2013.

24 B. Medyńska-Gulij, D. Lorek, Pruskie mapy topograficzne dla Wielkopolski do 1803 roku, „Badania Fizjograficzne nad Polską Zachodnią", 59, 2008, s. 37-38; A. Konias, Kartografia topograficzna państwa i zaboru pruskiego od II połowy XVIII wieku do połowy XX wieku, Słupsk 2010, s. 119-121. Mapa dostępna pod adresem: http:// igrek.amzp.pl/mapindex.php?cat=GILLYSKuSP, dostęp: 28.08.2013.

25 Klisze ze zdjęciami mapy i ich cyfrowe skany znajdują się pod sygnaturą Cg w Zakładzie Atlasu Historycznego (Instytut Historii im. Tadeusza Manteuffla PAN).

26 Więcej zob. Atlas historyczny Polski. Rejestry poborowe województwa kaliskiego w XVI w. red. M. Słoń (Atlas Żródeł i Materiałów do Dziejów Dawnej Polski, 2013-2014), http://atlasfontium.pl/index.php?article =p_kaliskie_XVIw, ISSN 2353-9216, dostęp: 17.06.2014.
}

inne zaś niszczały w wyniku powodzi, pożarów lub najazdów ${ }^{27}$.

Podstawą w pracach nad rekonstrukcją sieci młynów wodnych było stworzenie bazy zawierającej dane z poszczególnych źródeł i ustalenie ogólnej liczby obiektów przemiałowych we wszystkich interesujących mnie przedziałach czasowych połączonych z punktami przedstawiającymi wczesnonowożytne osadnictwo powiatu konińskiego ${ }^{28}$. Podczas prac pominięto dużą grupę XIV-wiecznych dokumentów klasztoru cysterskiego w Lądzie. Akta te zawierały bardzo ogólne, ale za to rozbudowane pod względem stylistycznym formularze znajdujące się w części narracyjnej. Na ogół młyny wodne pojawiały się tam obok innych obiektów gospodarczych i fizjograficznych, które - według ówczesnej maniery pisarskiej - powinny znajdować się w typowej wsi tego okresu. $\mathrm{Na}$ przykład starosta generalny Wielkopolski - Peregryn z Węgleszyna - poświadczył dokument sprzedaży wsi Sławęcin w 1387 r. na rzecz klasztoru w Lądzie „cum omni iure et dominio et cum omnibus utilitatibus, fructibus, censibus, proventibus, redditibus, obvencionibus, agris, pratis, pascuis, silvis, gaiis, mericis, borris, mellificiis, molendinis, lacubus, piscinis, aquis, paludibus et earum decursibus ac aliis omnibus et singulis pertinenciis [... ${ }^{22}$.

Uważny czytelnik zwróci także na pewno uwagę na bardzo skromne uwzględnienie w przedstawianej analizie wiatraków. Fakt ten wynika po pierwsze z bardzo słabego poświadczenia tego typu obiektów na terenach późnośredniowiecznego powiatu konińskiego, a po wtóre z warunków technologicznych i fizjograficznych, które - jak pokazało niedawne studium nad Krajną i Pałukami - miały całkiem

\footnotetext{
27 R. Kubicki, Młynarstwo w państwie, s. 293-311.

280 tworzeniu historycznych baz danych i ich znaczeniu dla Historical GIS zob.: I.N. Gregory, P.S. Ell, Historical GIS. Technologies, Methodologies and Scholarship, Cambridge 2007, s. 41-62; M. Naser, Digitale Karten zur Geschichte der Städte in Franken, Baunach 2010 , s. 32-42. Robocza baza, stworzona dla celów omawianej problematyki, nie została załączona do niniejszego tekstu, ponieważ wymaga ona szczegółowych uzupełnień w materiałach ksiąg grodzkich i sądowych przechowywanych w poznańskim archiwum.

$29 \mathrm{KDW}$, t. 6, nr 298.
} 


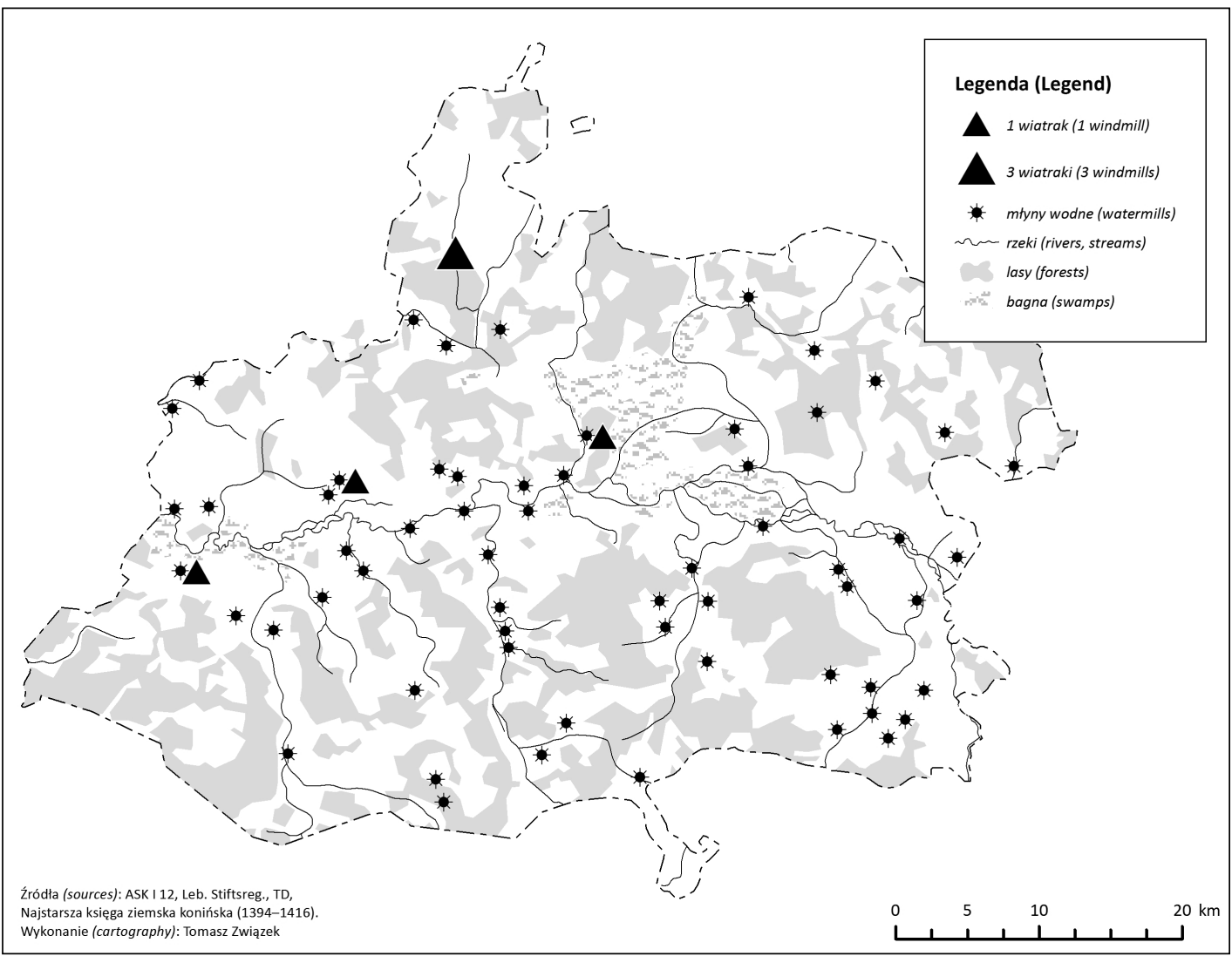

Mapa 2. Rozmieszczenie wiatraków na tle młynów wodnych w powiecie konińskim na początku XVI w.

znaczący wpływ na typ konstruowanych obiektów przemiałowych ${ }^{30}$. Na terytorium dawnego powiatu konińskiego występowało nie tylko stosunkowo duże zalesienie, które na podstawie XIX-wiecznej kartografii wynosiło około 30\% $\left(735 \mathrm{~km}^{2}\right.$ ) całości powiatu (ok. $2304 \mathrm{~km}^{2}$ ), ale także znajdowało się tam stosunkowo dużo drobnych cieków wodnych, które łączyły się bezpośrednio z Wartą. Wydaje się, że te warunki wystarczyły, by w całym powiecie konińskim na początku XVI w. funkcjonowało sześć poświadczonych źródłowo wiatraków: trzy w okolicach Kleczewa na najbardziej na północ wysuniętej części powiatu, jeden w Zagórowie położonym na południe od klasztoru cysterskiego w Lądzie oraz po jednym w Myśliborzu i Rudzicy ${ }^{31}$.

Taki stan identyfikacji wiatraków wynika także z faktu, że wszystkie obiekty przemiałowe w późnośredniowiecznych źródłach określano wspólnym mianem molendinum, dodając bardzo rzadko określenia ventile lub aquaticum. Pomimo zebrania pokaźnej liczby danych dotyczących dawnych młynów i wiatraków w powiecie konińskim nie zawsze udawało się jednoznacznie stwierdzić, że dany młyn służył produkcji spożywczej, czy też pełnił rolę folusza lub kuźni. Z drugiej strony warto zauważyć, że nie przeprowadzono też w tej sprawie kwerendy w archiwalnych księgach ziemskich i grodzkich dawnego powiatu konińskiego, które jako

30 T. Gidaszewski et al., Transformations of the Natural Landscapes of the Middle Noteć Region from the 10th to 16th Century, w: Landscapes and Societies in Medieval Europe East of the Elbe: Interactions Between Environmental Settings and Cultural Transformations, ed. S. Kleingärtner et al., Toronto 2013, s. 268-271.

310 słabym poświadczeniu wiatraków w źródłach późnośredniowiecznych zob. także w: Z. Podwińska, Rozmieszczenie wodnych, s. 381. 

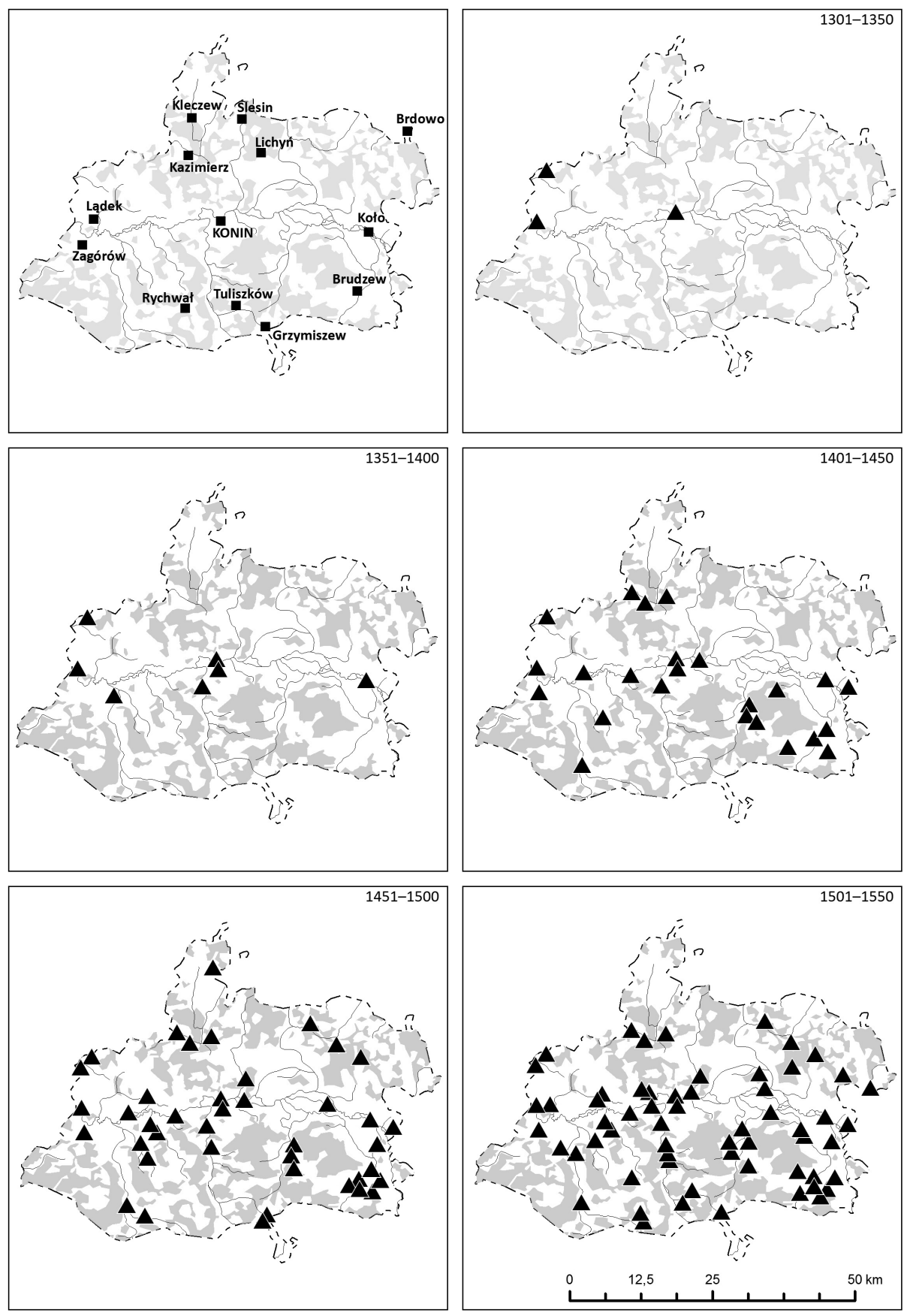

Legenda (Legend)

$\Delta$ młyny wodne (watermills) $\bigcirc$ lasy (forests)
rzeki (rivers, streams) i- granica (district border)

Wykonanie (cartography): Tomasz Związek

Mapy 3-8. Sieć młynów wodnych w powiecie konińskim (1300-1550) 
jedyne mogłyby wyjaśnić niektóre wątpliwości. Niestety nie podjęto także wyczerpujących studiów onomastycznych ${ }^{32}$.

Najważniejszymi z punktu widzenia tej pracy źródłami pozwalającymi na rekonstrukcję sieci młynów wodnych są najstarsze zachowane do naszych czasów rejestry poborowe dotyczące powiatu konińskiego z lat 1507-1510 i 1534-1535. Tematyka rejestrów poborowych była poruszana $\mathrm{w}$ dotychczasowej literaturze często $^{33}$. Spisy te, mimo oczywistych braków i trudności w ich interpretacji (a niekiedy i odczycie), są bardzo cenne. Są one nie tylko pierwszym źródłem dla przedrozbiorowej Polski, pozwalającym na przyjrzenie się ekonomii wsi i miast w skali całego powiatu lub województwa, ale także pozwalają na dokonywanie gospodarczych analiz porównawczych i przestrzennych dla danego terytorium w różnych przedziałach chronologicznych. Dodatkowym atutem jest możliwość stworzenia na podstawie informacji zawartych w rejestrach w miarę pełnego obrazu sieci osadniczej dla badanego terytorium, co stawia użyteczność rejestrów poborowych na poziomie podobnym do powszechnie znanych libri beneficiorum czy lustracji dóbr królewskich.

W dotychczasowej literaturze wskazywano, że pisarze sporządzający nadzwyczajne spisy podatkowe przepisywali wcześniejsze księgi, w związku z czym istniała poważna groźba, że dane w nich zawarte mogły być kopiowane $\mathrm{z}$ lat poprzednich ${ }^{34}$. Takie stwierdzenia mogłyby podawać w wątpliwość ich użyteczność w badaniu historycznym. Praktyka źródłowa dotycząca lat 1507-1510 pokazuje raczej, że były one zazwyczaj tworzone w sposób staranny i sumienny przez zatrudnionych pisarzy, którzy otrzymywali każdorazowo niemałą pensję za swoją pracę ${ }^{35}$.

32 B. Szady, Geografia historyczna w Polsce - rozwój i perspektywy, „Studia Geohistorica”, 1, 2013, s. 32-33. Por. E. Kowalczyk, Nazwy obronne Stup, Samborza i Zawada a zagadnienie obrony statej ziem polskich w średniowieczu, Warszawa 1992, s. 182-280.

33 Zob. przyp. 18

34 Tamże.

35 ASK I 12, k. 155v: „Item ex mandato generosi Jacobi Bothwrzynsky ego Gregorius Jaruch vicecollector per ratione salarii ab ista exactione sex marcas recepi". Zapiska ta jasno mówi także o pensji otrzymywanej przez urzędnika, która to nie różniła się znacząco od
Obraz uzyskany po naniesieniu danych źródłowych na mapę (Sieć mtynów wodnych..., s. 109) pozwala zaobserwować stopniowy przyrost obiektów przemiałowych w ciągu kolejnych półwieczy ${ }^{36}$. Analizując załączoną mapę, należy jednak pamiętać, że ukazuje ona liczbę młynów poświadczonych źródłowo dla danego okresu, a nie realnie istniejących w tym czasie. $\mathrm{Na}$ przykład w XIV-wiecznym powiecie konińskim funkcjonowało prawdopodobnie więcej niż siedem młynów wodnych. W związku z tym punkty przedstawione na mapie są konsekwencją zachowania bazy źródłowej, która dla tego okresu dotyczy albo dóbr klasztoru w Lądzie, albo wsi należących do starostwa konińskiego. Kolejne stulecie ma bardziej kompletną postawę źródłową, gdyż na początku XV w. przybyły chociażby księgi ziemskie i grodzkie. W związku z tym należy traktować przedstawione plany także jako pewnego rodzaju odzwierciedlenie rozwoju form kancelaryjnych i piśmienności urzędniczej badanego okre$\mathrm{su}^{37}$. Należy jednak pamiętać, że same księgi sądowe nie dają pełnego obrazu sieci młynów wodnych, a obraz z nich uzyskany charakteryzuje się dosyć dużą wybiórczością. Wynika to $\mathrm{z}$ prostego faktu, że sprawy w nich zapisywane dotyczyły jedynie przypadków kupna, sprzedaży, zastawu dóbr, rozgraniczeń lub konfliktów, w związku z czym zdarzało się, że istniejące obiekty przemiałowe nie pojawiały się w nich wcale, lub były wzmiankowane w rozbudowanych formularzach kancelaryjnych ${ }^{38}$.

Badanie sieci młynów wodnych, karczem, wiatraków, kuźnic, foluszy i innych obiektów gospodarczych poświadczonych na kartach źródeł powinno być tożsame $\mathrm{z}$ badaniami historii lokalnej, ponieważ nie należy analizować występowania tych obiektów bez ściśle okre-

standardów ówczesnej epoki. Por.: A. Bartoszewicz, Piśmienność mieszczańska w późnośredniowiecznej Polsce, Warszawa 2012 s. 152-158; T. Związek, Najstarszy rejestr, s. 173-179.

36 Zdecydowałem się rozważać zmiany w okresach 50-letnich, gdyż krótsze obserwacje (np. 10-letnie) nie ukazałyby dynamiki przemian. Takie postępowanie wynika także z dosyć niepełnych danych z XV w.

37 Por. R. Kubicki, Młynarstwo w państwie, s. 302-309.

38 Historia państwa i prawa Polski do roku 1795, t. 1, red. J. Bardach, Warszawa 1957, s. 477-481. 
ślonego kontekstu historycznego. Badania te w szczególności związane są z rozwojem areału łanowego i struktur osadniczych, które w ciągu wieków były tłem dla rozwoju (bądź regresu) liczby obiektów przemiałowych. Najważniejszym elementem - z punktu widzenia samych młynów wodnych i wiatraków oraz całego przemysłu zbożowego - były przede wszystkim rzeki i strumienie, a także działalność szlachty i możnowładców, którzy poprzez swoje decyzje ściśle wpływali - na równi z królem i duchowieństwem - na zarządzanie polityką przemiałową. Znaczenie uwarunkowań przyrodniczych jest tu także istotne, ponieważ to właśnie cieki wodne i prąd wody miały niemałe znaczenie dla lokalizowania kolejnych młynów oraz zarządzania nimi ${ }^{39}$. Jest to element o tyle ważny, że w wypadku centralnej części dawnego województwa kaliskiego - czyli powiatów pyzdrskiego, konińskiego i częściowo kaliskiego (poprzez dogodne położenie m.in. na linii Prosny) - rozwój tych terenów był ściśle związany $\mathrm{z}$ akcją osadniczą, dla której podstawą był po prostu jak najlepszy dostęp do wody.

W powiecie konińskim szczególne znaczenie miała Warta, o której zaletach pisał na przełomie XVIII i XIX w. Wawrzyniec Surowiecki, zwracający uwagę na to, że „ze względu na dostatek wód, iako też na umiarkowany ich spadek od 3. do 4. cali na 100. prętach, natura sama przeznaczyła tę rzekę do spławu i żeglugi. Liczne potoki, strugi i ieziora, za pomocą niekosztownych przekopów i upustów wszędzie ią mogą zasilać w każdey potrzebie i wśrzód wielkich suszy" ${ }^{40}$. Ekonomista pisał dalej w swojej książce, że „Polacy od naydawnieyszych czasów po Wiśle, uważali zawsze Wartę za naycelnieyszą rzekę kraiową; iey spławność tyle ich obchodzić musiała, ile ich obchodził odbyt na niewyczerpane płody wewnętrzne" ${ }^{\text {41 }}$. Co ciekawe, na przełomie wieków Surowiecki zauważył, że znaczna część Warty, jako rzeki transportowej była „zaniedbana od wieków, zatarasowana drzewem, kamieniami, groblami, iazami i młynami, dzieląc się na mnóstwo odnóg, i rozlewaiąc w wielu mieyscach na milę szeroko swoie wody, w dalekich tylko widokach, mogła ukazywać pożytki z poświęcanych prac i nakładów.
[...] Od Konina do Sieradza rzeka ta niezmiernie iest spustoszona; wszędzie widać, że albo gwałtem wypartą została z swego łoża, albo przez niedbalstwo dano się iey zupełnie zdziczeć. W niektórych mieyscach podzieliła się na mnóstwo drobnych odnóg, w których stoiące prawie wody, nie ukazuią żadnego podobieństwa do płynącey rzeki [...]"42.

Tak jak w epoce industrialnej, tak w późnym średniowieczu i nowożytności przykładano ogromną uwagę do gospodarki wodnej, dlatego też kwestia odpowiedniego regulowania spławów rzek była podnoszona chociażby na sejmach jagiellońskich w latach $1447^{43}, 1496^{44}$ i $1511^{45}$. Do głównych rzek Królestwa zaliczano wówczas m.in. Wisłę, Dniepr, Dniestr, Styr, Narew, Wartę, Dunajec, Wisłokę, Bug, Wieprz, San, Nidę, Prosnę i Noteć. Cieki te miały przede wszystkim znaczenie komunikacyjne. Budowa młynów wodnych mogła na co zwrócił już uwagę Surowiecki - poważnie zagrozić ich spławności, a w dalszej perspektywie utrudnić jakąkolwiek komunikację. W związku z tym zdecydowana część młynów wodnych zlokalizowana w powiecie konińskim znajdowała się wówczas na drobnych, ale za to licznych strugach i specjalnych młynówkach połączonych z większymi rzekami.

\section{Areał łanowy i kumulacja dóbr a kształtowanie sieci młyńskiej}

Opisywanie zależności przyrodniczych i gospodarczych związanych $\mathrm{z}$ warsztatami przemiałowymi jest niezaprzeczalnie powiązane $\mathrm{z}$ dziejami osadnictwa. Oczywistością jest, że wraz z jego postępem rozbudowywana była sieć

\footnotetext{
390 podobnych zjawiskach i ich znaczeniu zob. A. Kaniecki, D. Brychy, Wptyw antropopresji na przemiany środowiska przyrodniczego w średniowieczu w zlewni Obry Skwierzyńskiej, w: Zmiany stosunków wodnych w czasach historycznych, red. A. Kaniecki, A. Baczyńska, Poznań 2010, s. 115-127.

40 W. Surowiecki, 0 rzekach y spławach kraiów Xięstwa Warszawskiego, t. 1, Warszawa 1811, s. 48; M. Deszczyńska, Surowiecki Wawrzyniec, w: Polski Stownik Biograficzny [dalej: PSB], t. 46, z. 1, red. A. Romanowski, Kraków 2009, s. 12-17.

41 W. Surowiecki, 0 rzekach y spławach, s. 49.

42 Tamże, s. 56, 59.

43 VL, t. 1, s. 152-153.

44 Tamże, s. 69

45 Tamże, s. 244
} 
młynów i wiatraków ${ }^{46}$. Zastanawiające jest jednak to, na ile rozwój areału łanowego, warunki glebowe i leśne wpływały na rozwój tych zakładów, a na ile było to spowodowane polityką właścicieli ziemskich. Ciekawych przykładów tych mechanizmów dostarcza wspominana już wiadomo, jak te zjawiska wyglądały we włościach szlacheckich i kościelnych.

Na potrzeby niniejszego artykułu udało się dokonać zestawienia, które obrazuje w całkiem jasny sposób główne zależności pomiędzy łanami uprawnymi a obiektami przemiałowymi

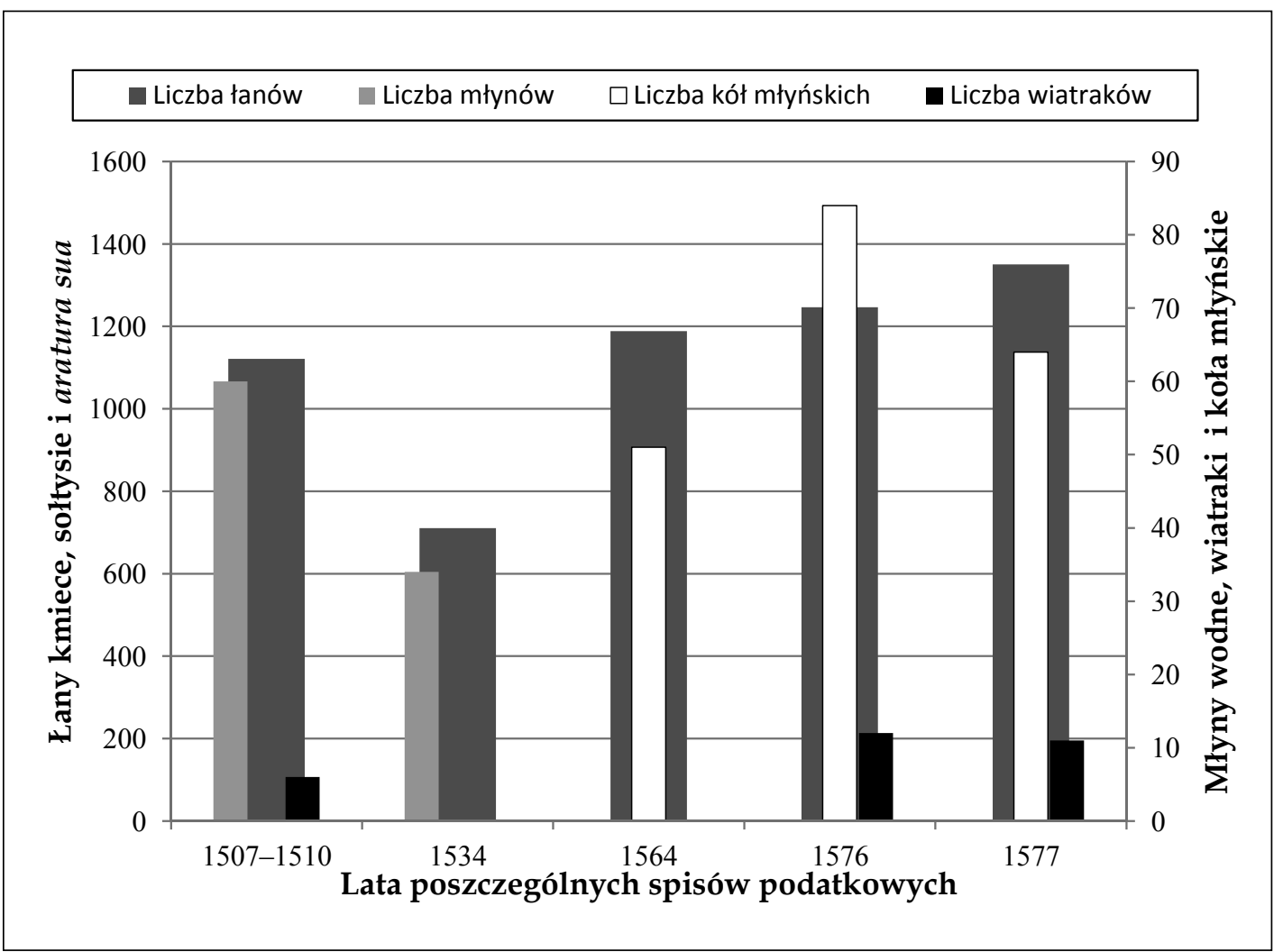

Wykres 1. Stosunek liczby fanów uprawnych do liczby obiektów przemiałowych (dane dotyczące całego powiatu). Żródto: AGAD, ASK I 12. Oprac. własne

wcześniej praca Rafała Kubickiego, który zauważył, że w państwie krzyżackim urzędnicy zakonni prowadzili całkiem rozsądną i ściśle przez nich kontrolowaną politykę opierającą się na stałym monitorowaniu wzrostu areału łanowego i dostosowywaniu liczby młynów wodnych i wiatraków do aktualnych potrzeb lokalnych społeczności ${ }^{47}$. Niestety nie do końca

\footnotetext{
46 Podobnie rozwijała się chociażby liczba karczem, jarmarków, targów i folwarków.

47 R. Kubicki, Młynarstwo w państwie, s. 293-294.
}

w ciągu niemal całego XVI w. (zob. Wykres 1). Oczywiście jest to wykres niepełny, ponieważ nie uwzględnia danych pochodzących z folwarków i przynależności dworskich, które także musiały oddziaływać na lokalny rynek przemiałowy. Zestawienie liczby łanów pozwala jednak - mimo wszystkich swoich braków - na pewne wyobrażenie tego, jakie miejsce w przestrzeni gospodarczej powiatu pełniły obiekty przemiałowe i na ile liczba młynów wodnych była związana z postępującym w XVI stuleciu rozwojem areału uprawnego. 
W przytoczonym wykresie celowo użyto danych wychodzących poza 1550 r. z powodu słabego zachowania rejestrów poborowych dla pierwszej połowy tego wieku. Niestety, należy także wspomnieć o tym, że najstarsze dane (m.in. pochodzące z lat 30. tego samego wieku) wymagają przeprowadzenia dogłębnej krytyki i porównania ich $\mathrm{z}$ materiałem pochodzącym $\mathrm{z}$ sąsiednich powiatów, dlatego $\mathrm{w}$ analizie użyto - w kontrolnej postaci (poza najstarszymi rejestrami z lat 1507-1510) - tylko spisu z 1534 r. Kolejnym wątpliwym spisem podatkowym jest także ten, który został przeprowadzony w 1576 r., gdyż liczba kół młyńskich znajdujących się w tabeli zdecydowanie nie koresponduje ze spisami z lat 1564 i 1577 . Niestety na tym poziomie badań nie było możliwe dokonanie pełnej krytyki tego rejestru poprzez porównanie go z materiałem pochodzącym $\mathrm{z}$ innych powiatów dawnego województwa kaliskiego.

Mimo wspomnianych zastrzeżeń dotyczących wartości analizowanych źródeł zaprezentowane w postaci wykresu dane pozwalają na ścisłe połączenie produkcji zbożowej z przemysłem młyńskim. Tę zależność widać w szczególności na podstawie rejestrów z 1564 i 1577 r., kiedy to wraz z przyrostem areału łanowego zwiększała się liczba opodatkowanych kół młyńskich. Stosunek ich liczby do areału tanowego wynosił w obu tych latach około 20-22 łanów do jednego koła, co jasno pokazuje korelacje $\mathrm{z}$ wnioskami dotyczącymi dostosowywania danej gałęzi przemysłu do aktualnych potrzeb gospodarczych wyciagnniętymi przez Rafała $\mathrm{Ku}-$ bickiego dla terenów państwa krzyżackiego ${ }^{48}$. Warto zauważyć także, że przez cały XVI w. przemiał prowadzony w wiatrakach odgrywał rolę drugorzędną, gdyż liczba tych obiektów wahała się od 6 na początku wieku do 11-12 w jego trzeciej ćwierci. Niezwykle ciekawym

\footnotetext{
48 Tamże.

49 Por. P. Guzowski, Wptyw eksportu zboża na produkcje pszenicy i jęczmienia na rynki lokalne w drugiej połowie XVI wieku, w: Rynki lokalne i regionalne W XV-XVIII wieku, red. P. Guzowski, K. Borody, Białystok-Kraków 2013, s. 87-106.

$50 \mathrm{~K}$. Boroda, Rynek produkcji piwa i handlu alkoholem w woj. tęczyckim w XVI wieku, w: Rynki lokalne i regionalne w XV-XVIII wieku, red. P. Guzowski, K. Boroda, Białystok-Kraków 2013, s. 55-85.
}

doświadczeniem byłaby w tym wypadku próba oceny profilu produkcji zbożowej prowadzonej w gospodarstwach starościńskich powiatu konińskiego i powiązania tych analiz z ewentualnym rozwojem sieci młynów wodnych ${ }^{49}$.

Młyny wodne w swym najprostszym podziale miały charakter albo spożywczy (przemiał zboża, produkcja kaszy i słodów), albo przemysłowy (folowanie sukna, obróbka darniowych rud żelaza etc.). Zdaje się, że dogodne warunki fizjograficzne, ale i gospodarcze powiatu konińskiego pozwalały na ukierunkowanie produkcji młyńskiej praktycznie tylko w kwestii spożywczej, gdzie słód odgrywał raczej mniejszą rolę. Dowodami mogą być zjawiska, jakie miały miejsce w sąsiedniej ziemi sieradzkiej i łęczyckiej oraz w powiecie pyzdrskim. Dotychczasowe badania Krzysztofa Borody nad przemystem piwnym w przedrozbiorowej Polsce pokazały, że w ziemi sieradzkiej i łęczyckiej znajdowały się najważniejsze miejsca wyrobu piwa w całej XVI-wiecznej Koronie ${ }^{50}$. Stamtąd też zapewne importowano słód i piwo na zachód Wartą. Być może właśnie ten czynnik spowodował, że nie udało się uchwycić większej liczby młynów wodnych wytwarzających słód w powiecie konińskim. Warto także pamiętać o tym, że dane z drugiej połowy XVI w., a odnoszące się do powiatu pyzdrskiego, sugerują, że miało w nim miejsce wyspecjalizowanie się młynów produkujących sukno ${ }^{51}$. Takie warunki gospodarcze okolicznych terenów mogły jasno ukierunkować przemysł powiatu konińskiego w stronę przetwórstwa zbożowego z minimalnym zaopatrywaniem w sukno w foluszach znajdujących się na pewno w Koninie i Kole ${ }^{52}$. Niestety w trakcie prac nie udało się odnaleźć wzmianek mówiących o kuźnicach lub tartakach znajdujących się w powiecie konińskim, chociaż zapewne obiekty takie musiały w nim istniećs3

${ }^{51}$ A. Mączak, Sukiennictwo wielkopolskie. XIV-XVII wiek, Warszawa 1955, s. 31-34, 41-48, 224-225; M. Kamler, Folwark szlachecki w Wielkopolsce w latach 1580-1655, Warszawa 1976, s. 103-106. 52 Tamże, s. 259-260; T. Związek, Testament młynarza, s. 163-165.

53 Por.: KDW, t. 7, nr 432 - król nadaje prawo do budowy tartaku na Prośnie, z którego 1/3 dochodów została przekazana Kaliszowi; tamże, t. 8, nr 964 - monarcha nadaje prawo do budowy młyna rudnego nad Oleśnicą w powiecie kaliskim. 

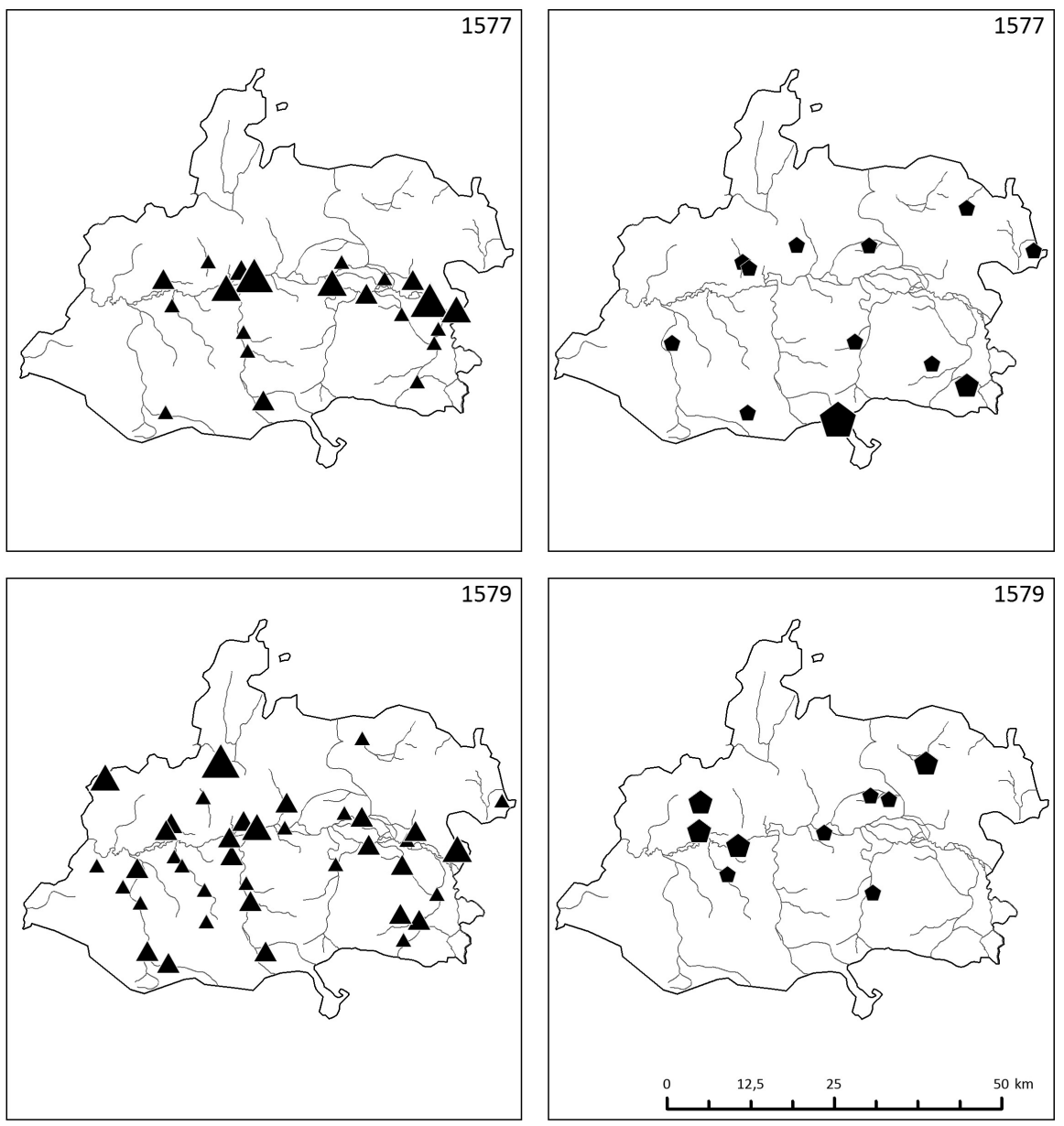

\section{Legenda (Legend)}
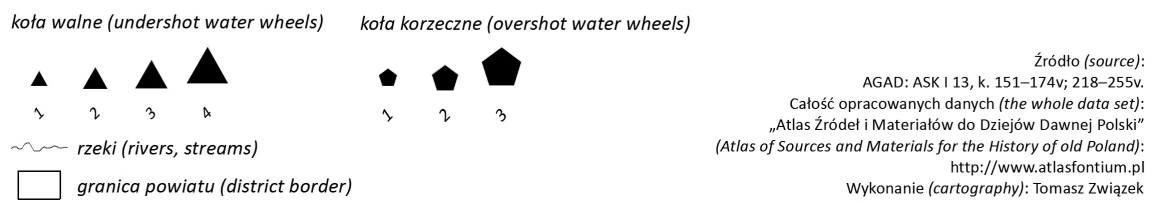

Mapy 9-12. Rozmieszczenie młynów o kołach walnych i korzecznych w drugiej połowie XVI w.

Rozwój przemysłu młynarskiego w powiecie konińskim obserwuje się także poprzez rozmieszczenie różnych typów obiektów przemiałowych budowanych na drobnych rzekach i strumieniach przepływających przez powiat koniński. Młyny podsiębierne (walne) były konstruowane najczęściej na strumieniach, takich jak Czarna, Pokrzywnica, Topiel i Kiełbaska oraz na młynówkach powiązanych ściśle z Wartą (zob. okolice Konina i Koła). Młyny nasiębierne (korzeczne) były natomiast dodatkiem budowanym na terenach o słabych warunkach hydrograficznych ${ }^{54}$. W 1577 r. kół walnych wzmiankowanych w rejestrach było 48 ,

\footnotetext{
54 Zob. mapę Rozmieszczenie mtynów o kołach walnych i korzecznych w drugiej pot. XVI wieku. Por. D. Brykała, Rekonstrukcja retencji, s. 78-82.
} 
a korzecznych 12; podobnie w 1579 , gdzie stosunek wynosił 76 kół dziedzicznych do 15 dzierżawnych ${ }^{55}$. Młyny korzeczne pomimo znaczącej wartości przerobowej były konstrukcjami droższymi i trudniejszymi w utrzymaniu, przez co były one częściej dzierżawione młynarzom niż przez nich wykupywane ${ }^{56} . Z$ tego powodu w drugiej połowie XVI w. obserwuje się proces utożsamiania obiektów dziedzicznych z konstrukcją podsiębierną (koła walne), a dorocznych z nasiębierną (koła korzeczne) ${ }^{57}$. Warto pamiętać także o tym, że obiekty podsiębierne - zdecydowanie łatwiejsze w eksploatacji - były bezpieczniejszym źródłem zysku, bo mniej podatnym na sytuacje niecodzienne, jak na przykład pękanie grobli; groziły im za to częste wylewy rzek, chociaż niektóre młyny miały koła mocowane na specjalnych wagach regulujących ich poziom (tzw. młyny ważne), co pozwalało na dostosowanie wysokości koła do aktualnego poziomu wody ${ }^{58}$. Ciekawym uzupełnieniem opisywanych spraw są pochodzące z XVI w. skargi młynarzy, które spływały do członków kapituły gnieźnieńskiej. W źródłach można przeczytać między innymi o tym, że: „mlyn, kthory oczyecz moy y przodek nas kupyl za pyenyadze sa swe y uzywal thego mlynna od kyladzyessyad lad, w pokoyu bedacz, a nygdy zadnego przenagabanya nyemyal od zadnego xyedza Arczybyskupa, abowyem placzylysmy czyns then, kthory mamy na prawye y wyeprza karmylysmy, yako y drudzy mlynarze, y pobudowalysmy swym nakladem, swym grossem, czo nass tho barzo wyelye kosthuye [...]" ${ }^{\prime \prime}$. W innej skardze suplikant pisał: „Ia [...] Stanyslaw młynarz [...] przed W[asse]. M[osczi]. szwe dolieglosczi opowiadam, yakom tess pierwei yuss tho dwie lyeczie

55 J. Matuszewski, Molendinum manuale, „Studia i Materiały do Dziejów Wielkopolski i Pomorza”, 13 (25), 1979, s. 127-144. Polemika: M. Dembińska, , Ręczny”, , doroczny", czy „w pańskim rę̧u”? Nieco o terminologii źródeł polskich, „Studia Źródłoznawcze”, 26, 1981, s. 190-192.

56 T.S. Reynolds, Stronger than a hundred men: A History of the Vertical Water Wheel, Baltimore 2003, s. 11.

57 Praktyka taka była realizowana przykładowo w rejestrze poborowym powiatu poznańskiego z 1553 r. Zob. ASK I 5, k. 153 i n.

58 Za tę informację dziękuję prof. Elżbiecie Kowalczyk-Heyman z Instytutu Archeologii Uniwersytetu Warszawskiego. 0 młynie zwanym ważnym zob. T. Jurek, Kilkanaście niedrukowanych dotąd dokumen- opowiadal, które mam przess tak dlugi czas oth xziedza Rudnyczkiego y oth yego urzednyka, któremu to xziedzu Rudnyczkiemu, gdim oth W[assych]. M[ossczi]. dal lysth, przeczitawssi go, rzuczil go na mye, mówiacz: ycz ze $\boldsymbol{s}$ nym zassie do kapythuly, a wymyatay ze my ssie ze mlyna [podkreślenie moje - T.Z.] [...]"60.

Skargi pokazują nie tylko codzienne trudy i zmartwienia młynarzy, ale także różne podchodzenie do form własności obiektu przemiałowego. Źródła jasno wskazują, że młynarz dziedziczny pracujący w młynie należącym do rodziny miał mocniejszą pozycję $\mathrm{w}$ relacjach z właścicielem dóbr niż osoba, która taki obiekt dzierżawiła. Szczególnie ważne było to w odniesieniu do obiektów zepsutych i opuszczonych, bezużytecznych dla okolicznej społeczności, która musiała pokonywać większe odległości w celu przetworzenia zboża. Był to także problem dla właścicieli dóbr, którzy w każdym sezonie tracili całkiem spore dochody. Warto jednak dodać, że znalezienie odważnego młynarza bywało zadaniem trudnym i niejednokrotnie przerastającym wielu chętnych ${ }^{61}$.

Dość trudno prześledzić rozwój młynarstwa w powiecie konińskim na tle XIV-wiecznych procesów lokalizacyjnych, gdyż źródła dla tego okresu są zbyt skromne. Tak samo na obecnym poziomie badań nie można pozwolić sobie na zbyt dokładne analizy ukazujące ścisły związek budowy młynów wodnych i wiatraków w kontekście rozwoju osadnictwa XV-wiecznego w województwie kaliskim. Jeszcze za mało wiadomo o kluczach dóbr, ich funkcjonowaniu i polityce właścicieli $\mathrm{w}$ badanym okresie w ujęciu szczegółowym i horyzontalnym.

$\mathrm{Na}$ badanym terytorium przeważały gleby lekko i średnio gliniaste, położone w większej

tów wielkopolskich, w: Fontes et historia. Prace dedykowane Antoniemu Gąsiorowskiemu, Poznań 2007, s. 109. Młyn taki znajdował się w badanym okresie na Warcie w okolicach Konina.

59 Księgi sądowe wiejskie, t. 1 [dalej: KsWiej I], wyd. B. Ulanowski, Kraków 1921, nr 4571. Por. nr 4579 i 4603.

60 Tamże, nr 4574.

61 Tamże, nr 4603: „Widzącz teras niekthorzy młynarze, izem poprawił niemało, y teraz się thego młyna domagaią, na on czas moi łaskawi Panowie nie dbali zań, poki byl oblamani, ale się im therasz spodobała narzenda moia, tak ze theras nie ieden się go dopira radzi by mię s niego wignali [...]". 
części w północnej oraz południowo-zachodniej części powiatu, gdzie znajdowało się około $45 \%$ wszystkich osad wiejskich ${ }^{62}$. Dodatkowo ten typ gleb występował także w okolicach parafii Kościół (na zachód od Koła) i w przyległościach Brudzewa. Podstawowa analiza wpływu jakości gruntów na proces osadniczy jasno pokazuje, że największe parafie wysokołanowe znajdowały się na terenach gliniastych bądź położonych na styku tychże z czarnoziemami - jak w wypadku okolic Lądku i Kleczewa. Bardzo ciekawym przykładem są przyległości Tuliszkowa, które nie cechowały się ani stosunkowo dużą liczbą osad, ani dobrymi glebami (dominowały tam głównie bielice). Intensywna akcja kolonizacyjna i polityka rozwoju dóbr wpływała pozytywnie na rozwój gospodarczy każdego z tych małych regionów, które wraz ze wzrostem areału łanowego potrzebowały zakładów przetwarzających zboże. Należy jednak pamiętać o tym, że kształtowanie sieci młynów wodnych (jak i każdej innej sieci obiektów gospodarczych) było sprzężone zwrotnie z rozwojem osadnictwa, które dla terenów Wielkopolski jest nadal stosunkowo słabo przebadane ${ }^{63}$.

Na proces kształtowania sieci młynów wodnych istotny wpływ miała także polityka obrotu dobrami przez szlachtę, Kościół i monarchę. Każdy z tych właścicieli starał się uzyskać bogate dobra lub wygenerować jak największe dochody z włości już zarządzanych. Przeglądając materiał gospodarczy, można zauważyć pewne prawidłowości związane $\mathrm{z}$ administrowaniem odpowiednimi dobrami. Dla tej analizy posłużono się przykładami dóbr królewskich okolic Konina i szlacheckich skupionych wokół rodziny Brudzewskich herbu Pomian. Niestety zagadnienie rozwoju gospodarczego wsi należących do biskupów lubuskich w Kazimierzu i klasztoru cysterskiego w Lądzie wymagają zupełnie osobnego potraktowania,

\footnotetext{
62 Podczas pracy korzystano z Mapy gleb Polski, 1:300 000, red. A. Musierowicz, Warszawa 1961.

63 Nie chodzi tu o punktowe badania, opisujące funkcjonowanie pojedynczych kluczy dóbr, a raczej o pracę pokazującą główne mechanizmy akcji osadniczej wraz z jej konsekwencjami dla większej części województwa poznańskiego czy też kaliskiego.
}

gdyż dotychczas zgromadzone materiały, pomimo wspominania o młynach wodnych, nie dają dużego pola do rzetelnej analizy ekonomicznej ${ }^{64}$.

Sprawa młynów wodnych znajdujących się w dobrach królewskich była obiektem dużego zainteresowania ze strony wczesnonowożytnego aparatu skarbowego, o czym świadczą nie tylko uchwały sejmowe, ale także dosyć szczegółowe lustracje tych kompleksów ${ }^{65}$. Taka polityka króla nie dziwi, jeżeli weźmie się pod uwagę, że domena należąca do niego miała służyć nie tylko realizowaniu realnej polityki poprzez zaspokajanie potrzeb - jak nazwał to Jan Worniszewski - „budżetowych”, ale także budowaniu zaplecza osobowego dla planów monarszych w wyniku licznych nadań ${ }^{66}$. Najlepiej oświetlonym źródłowo przykładem w powiecie były dobra starostwa konińskiego, dla których sporządzono dokładne inwentarze w latach 1511, 1559 i 1564. Znaczenie tych dóbr w skali lokalnej, ale także całego województwa kaliskiego, było całkiem duże, gdyż włości tenutariusza pod koniec XVI w. wynosiły około $14 \%$ całości wsi królewskich, natomiast areał uprawny sięgał niemal 18\% wszystkich ziem w województwie kaliskim ${ }^{67}$.

Według najstarszych inwentarzy i spisów podatkowych ok. 1511 r. w 12 wsiach należących do starostwa uprawiano ok. 107 łanów obsługiwanych przez 4 młyny znajdujące się we wsiach Czarnków, Stare Miasto i Rumino ${ }^{68}$. Młynarze zapytani o prowadzony wówczas przemiał nie umieli (lub też nie chcieli) odpowiedzieć lustratorom, jakie ilości zbóż zmełli w ostatnim roku oraz jakie dochody

64 Tematyka dóbr kościelnych będzie prawdopodobnie przedmiotem osobnego tekstu.

65 K. Boroda, Kmieć, tan czy profit? Co było podstawą poboru tanowego w XV i XVI wieku?, w: Człowiek wobec miar i czasu w przesztości red. P. Guzowski, M. Liedke, Kraków 2007, s. 152-170.

66 J. Worniszewski, Król jako właściciel ziemski w średniowiecznej Polsce, w: Król w Polsce XIV i XV wieku, red. A. Marzec, M. Wilamowski, Kraków 2006, s. 120-128.

67 Wyliczenia zaczerpnięto z: Lustracje i inwentarze, s. 106-107.

68 Lustracja 1511. Wśród wsi starościńskich tego okresu znajdowały się: Czarnkowo, Chorzeń, Międzylesie, Morzysław, Patrzychowo, Krąpsko, Stare Miasto, Barczigłowo, Rumino, Głowiewo i Wilkowo. Dopiero lustracja 1564 r. wspominała jeszcze o wsiach Modła Królewska i Lisiec Wielki. Szerzej zob.Tabela 1. 
Tab. 1. Inwentarz wsi starostwa konińskiego w latach 1507-1564

\begin{tabular}{|c|c|c|c|c|}
\hline Miejscowość & $\begin{array}{c}\text { Rejestry poborowe } \\
1507-1510 \mathrm{r} .\end{array}$ & Lustracja 1511 r. & Lustracja 1559 r. & Lustracja 1564 r. \\
\hline Czarnkowo & $\begin{array}{c}\text { „Molendinum } \\
\text { C[z]arnkow" }-3 \text { koła } \\
\text { (w tym jedno spusto- } \\
\text { szone) }\end{array}$ & $\begin{array}{c}\text { folwark, } 2 \text { młyny (jeden } \\
02 \text { kołach, drugi także } \\
02 \text { kołach zw. „Piscorzow”); } \\
3 \text { tany kmiece; } 3 \text { rybaków }\end{array}$ & $\begin{array}{l}\text { folwark; } 3 \text { tany kmiece; } \\
2 \text { karczmy; } 4 \text { rybacy }\end{array}$ & $\begin{array}{c}\text { folwark; } 3 \text { tany kmiece; } \\
2 \text { karczmy; } 2 \text { ogrodników; } \\
5 \text { rybaków; } 2 \text { młyny na Warcie } \\
\text { (jeden: } 2 \text { koła mączne - walne; } \\
\text { trzecie stępne; drugi: } 2 \text { koła } \\
\text { mączne - walne) }\end{array}$ \\
\hline Chorzeń & 1 tan kmiecy & $\begin{array}{l}10 \text { tanów uprawnych; } \\
5 \text { tanów opustoszałych; } \\
1 \text { osoba luźna }\end{array}$ & $\begin{array}{l}13 \text { tanów kmiecych; } 3 \text { tany } \\
\text { puste; } 1 \text { tan karczemny } \\
\text { [karczma]; młyn }\end{array}$ & $\begin{array}{l}13 \text { łanów kmiecych; } 2 \text { tany } \\
\text { puste; karczma; młyn na } \\
\text { Warcie (2 koła mączne; } \\
1 \text { koło folusznicze) }\end{array}$ \\
\hline Międzylesie & $\begin{array}{l}5 \text { tanów kmiecych; } \\
1 \text { tan opuszczony }\end{array}$ & $\begin{array}{l}5 \text { tanów kmiecych; } 2 \text { tany soł- } \\
\text { tysie - nie płacą; } 1 \text { łan soltysi } \\
\text { pusty; } 13 \text { tanów pustych }\end{array}$ & $\begin{array}{l}6 \text { tanów kmiecych; } 2 \text { tany } \\
\text { soltysie; } 12 \text { łanów pustych }\end{array}$ & $\begin{array}{l}7 \text { tanów kmiecych; } 11 \text { tanów } \\
\text { pustych; } 2 \text { lany soltysie }\end{array}$ \\
\hline Morzysław & - & $\begin{array}{c}4 \text { tany kmiece }(6 \text { kmieci); } \\
\text { 1,5 tana pustego; } 2 \text { karczmy } \\
\text { opuszczone }\end{array}$ & $\begin{array}{l}8 \text { tanów kmiecych; } 1 \text { tan } \\
\text { pusty; } 5 \text { ogrodników; } 1 \text { tan } \\
\text { należących do rybaków; } \\
2 \text { rybaków }\end{array}$ & $\begin{array}{c}8 \text { tanów kmiecych; } 1 \text { tan pu- } \\
\text { sty; karczma (nowa - nie płaci } \\
\text { podatku); } 5 \text { pustych ogrodów; } \\
1 \text { rybak }\end{array}$ \\
\hline Patrzychowo & 1 tan kmiecy & $\begin{array}{l}7 \text { tanów kmiecych; } 7 \text { tanów } \\
\text { opuszczonych }\end{array}$ & $\begin{array}{l}15 \text { tanów kmiecych; } \\
5 \text { zagrodników }\end{array}$ & $\begin{array}{l}15 \text { tanów osiadłych; } \\
5 \text { zagrodników }\end{array}$ \\
\hline Krąpsko & 4 tany kmiece & $\begin{array}{l}\text { mały folwark (prediollum } \\
\text { parvum); } 6 \text { tanów kmiecych; } \\
2 \text { tany opuszczone }\end{array}$ & $\begin{array}{c}\text { folwark; } 7 \text { łanów kmiecych; } \\
1 \text { tan pusty; } 3 \text { zagrodników; } \\
\text { karczma; młyn } \\
\text { (1 koło korzeczne) }\end{array}$ & $\begin{array}{l}\text { folwark; } 7 \text { tanów kmiecych; } \\
3 \text { zagrodników; karczma; młyn }\end{array}$ \\
\hline Stare Miasto & młyn & $\begin{array}{l}\text { folwark; } 3 \text { tany kmiece; młyn } \\
\text { na strumieniu Golanka. }\end{array}$ & $\begin{array}{c}\text { folwark; } 3 \text { łany kmiece; } \\
3 \text { soltysów; } 9 \text { tanów wolnych } \\
\text { od podatków - służba zamko- } \\
\text { wa; karczma; } 1 \text { tan pusty; } \\
2 \text { zduni; młyn zw. Dębowy } \\
\text { (2 koła zbożowe; } \\
1 \text { koło folusznicze) }\end{array}$ & $\begin{array}{l}\text { folwark; } 3 \text { tany kmiece; } \\
5 \text { łanów pustych; karczma; } \\
2 \text { zagrodników; } 9 \text { tanów } \\
\text { zwolnionych od podatków; } \\
3 \text { łany soltysie; mączny młyn } \\
\text { na Pokrzywnicy z kołem } \\
\text { foluszniczym }\end{array}$ \\
\hline Barczigłowo & 3 tany kmiece & $\begin{array}{l}3 \text { tany kmiece; } 2 \text { soltysów } \\
\text { (Piotr i Mikołaj) [2 tany?] }\end{array}$ & $\begin{array}{l}5 \text { tanów kmiecych; } 7 \text { tanów } \\
\text { pustych; } 2 \text { tany soltysie; } \\
\text { karczma }\end{array}$ & $\begin{array}{l}5 \text { łanów kmiecych; } 5 \text { tanów } \\
\text { pustych; } 2 \text { tany sołtysie }\end{array}$ \\
\hline Rumino & $\begin{array}{l}7 \text { tanów kmiecych } \\
\text { (w tym } 1 \text { tan zwol- } \\
\text { niony); młyn zw. } \\
\text { Prandotha (1 koło) }\end{array}$ & $\begin{array}{l}8 \text { tanów kmiecych (2 kmieci } \\
\text { ma po } 0,5 \text { tana); } 3,5 \text { tana } \\
\text { opuszczonego; młyn }\end{array}$ & $\begin{array}{l}\text { folwark (3 łany); } 12 \text { łanów; } \\
\text { karczma; } 2 \text { łany soltysie; młyn } \\
\text { zw. Romiński (2 koła); młyn } \\
\text { zw. „Prandota” (2 koła) }\end{array}$ & $\begin{array}{c}\text { folwark; } 9 \text { tanów kmiecych; } \\
\text { karczma; } 4 \text { zagrodników; } \\
2 \text { tany sottysie; młyn na } \\
\text { Warcie (1 koło walne); młyn } \\
\text { zw. „Prądota” na Pokrzywnicy } \\
\text { (2 koła walne) }\end{array}$ \\
\hline Glowiewo & $\begin{array}{l}25 \text { łanów kmiecych; } \\
2 \text { karczmy }\end{array}$ & $\begin{array}{l}20,5 \text { tana kmiecego; } 4,5 \text { tana } \\
\text { opuszczonego; } 3 \text { karczmy; } \\
\text { soltys }\end{array}$ & $\begin{array}{l}26 \text { tanów kmiecych; } \\
4 \text { karczmarzy; zdun }\end{array}$ & $\begin{array}{l}26 \text { łanów kmiecych; } \\
4 \text { karczmarzy; zdun; } \\
4 \text { tany sołtysie }\end{array}$ \\
\hline Borzętowo & 15 tanów kmiecych & $\begin{array}{l}20 \text { tanów kmiecych ( } 4 \text { kmieci } \\
\text { ma po } 0,5 \text { tana); } 4 \text { tany } \\
\text { opuszczone }\end{array}$ & - & 23 tany kmiece; 2 tany soltysie \\
\hline Wilkowo & 8 tanów & $\begin{array}{c}8,5 \text { tana kmiecego; } 7,5 \text { tana } \\
\text { opuszczonego; } 4 \text { tany sottysie }\end{array}$ & $\begin{array}{c}\text { folwark (4 tany puste); } 9 \text { tanów } \\
\text { kmiecych; } 3 \text { tany puste; } \\
4 \text { tany soltysie }\end{array}$ & $\begin{array}{l}\text { folwark (7 tanów); } 9,5 \text { tana } \\
\text { kmiecego; } 7 \text { tanów pustych; } \\
2 \text { tany soltysie }\end{array}$ \\
\hline Modła Królewska & - & - & $\begin{array}{l}8 \text { tanów kmiecych; } 1 \text { tan } \\
\text { pusty; karczma; } 1 \text { zagrodnik }\end{array}$ & $\begin{array}{l}8 \text { tanów kmiecych; } \\
1 \text { lan pusty; karczma }\end{array}$ \\
\hline Lisiec Wielki & - & - & $\begin{array}{l}\text { folwark (1 łan); } 15 \text { łanów } \\
\text { kmiecych; } 4 \text { karczmarzy; } \\
1 \text { kmieć, który warzy piwo } \\
\text { w domu; } 2 \text { zagrodnicy; } \\
\text { smolarze; } 2 \text { młyny }\end{array}$ & $\begin{array}{l}\text { folwark; } 15 \text { tanów kmiecych; } \\
4 \text { karczmarzy; } 2 \text { zagrodników; } \\
\text { młyn mączny na Pokrzywnicy } \\
\text { (1 koło walne); młyn mączny } \\
\text { na Pokrzywnicy (1 koło walne) }\end{array}$ \\
\hline
\end{tabular}

Źródło: Lustracja 1511, Lustracja 1559, Lustracja 1564, ASK I 12, k. 148-206. Oprac. własne 
z nich uzyskali ${ }^{69}$. Należy jednak założyć, że sytuacja ekonomiczna starostwa z czasem się poprawiła, gdyż w inwentarzu sporządzonym w 1559 r. notujemy już aż dziewięć obiektów: folusz położony przy młynie zwanym Dembowy (służącym najprawdopodobniej do obróbki kory dębowej) oraz trzy młyny wybudowane na Warcie i cztery pracujące na pobliskiej strudze Pokrzywnicy ${ }^{70}$. Obiekty te obsługiwały w owym czasie mniej więcej 250 łanów uprawianych we wsiach i folwarkach starostwa ${ }^{71}$. go średniowiecza i wczesnej nowożytności. Tak intensywny rozwój przemysłu młynarskiego na pewno należy wiązać od około połowy XVI w. z postępującą ewolucją instytucji folwarków i stopniowym poszerzaniem areału uprawnego, a także ze wzrostem liczby ludności ${ }^{72}$.

O szczególnym podejściu monarchy do budowy młynów i czerpania $z$ nich dochodów świadczyć mogą także XIV- i XV-wieczne dokumenty wystawiane dla Koła i Konina. Pierwszy dokument potwierdzający funkcjo-

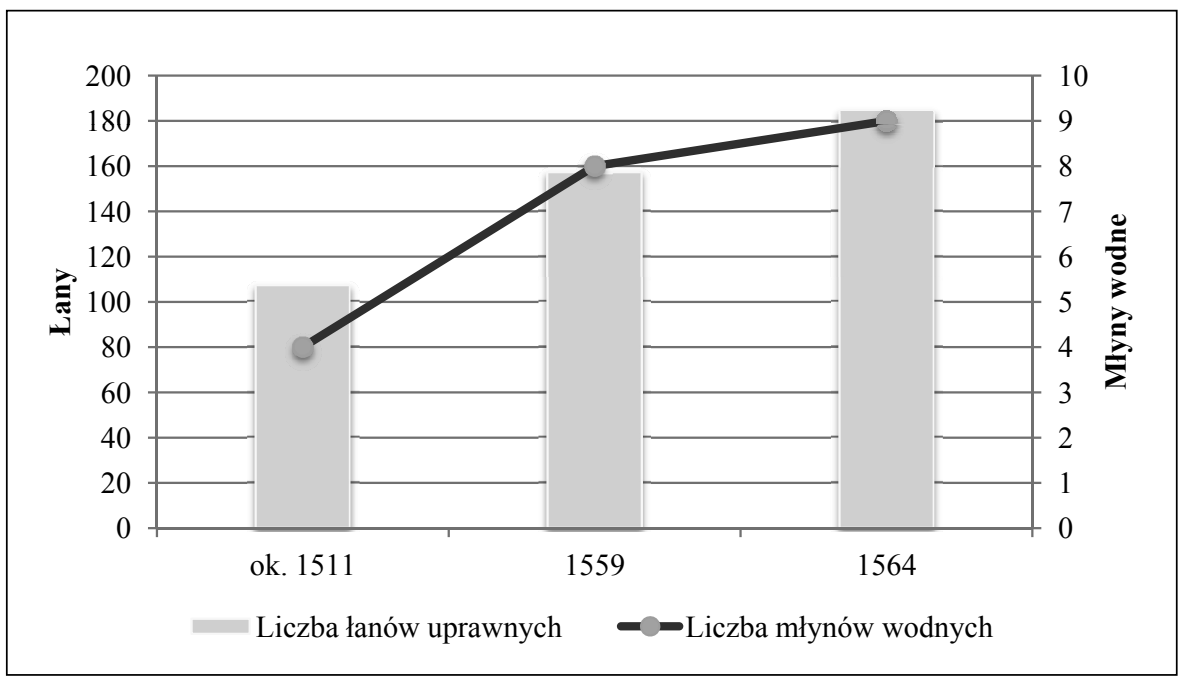

Wykres 2. Rozwój liczby młynów wodnych w starostwie konińskim na tle rozwoju areału łanowego. Źródto: Tabela 1

Dane zestawione powyżej jasno pokazują, że przemiał zboża był jednym z podstawowych źródeł dochodów monarszych (a precyzyjniej osób dzierżawiących te dobra) w epoce późne-

69 Tamże, s. 111: „In villa Czarnkowo [...] burgrabius et cum molendinatoribus ignorabant dicere, quid ex eis provenit ad annum, quia unquam conscribebat [s] nec alias karbovali"; tamże, s. 113: „Item in Antiquo Suburbio [...] est molendinum [...] aquaticum et ignotatur [s], qui faciet ad annum".

70 Młyn ten należy prawdopodobnie utożsamiać z obiektem wzmiankowanym w 1450 r. w przywileju Kazimierza Jagiellończyka dla wdowy Katarzyny oraz jej synów: Jana i Stanisława. Zob. Knigi polskoj koronnoj mietriki XV stoletija, wyd. T. Wierzbowski, Warszawa 1914, nr 113, s. $97-99$.

71 Tamże, s. 140-141. Zob. E. Wolnicz-Pawłowska, Nazwy wodne dorzecza Warty od źródeł do ujścia Prosny, Warszawa 2006, s. 143-144. Każdy z tych młynów znajdował się w odlegtości mniej więcej 3-4 km od miasta. 0 młynach przynależnych do starostwa konińskiego zob. nowanie młyna wodnego w Koninie znany jest z przywileju Kazimierza Wielkiego z 1359 r. dla Wilhelma (mieszkańca Sieradza), któremu król nadał wójtostwo w mieście ${ }^{73}$. Kolejny,

także: Civitas Conyn. Dzieje miasta i starostwa do schyłku XVIII w. red. J. Łojko, t. 1, Konin 2011, s. 210-211.

72 Do bardzo podobnych wniosków doszedł Marcin Kamler, który pisał, że „wraz ze wzrostem areału i liczby poddanych nie tylko wzrasta odsetek wsi z młynami, lecz także coraz czesstsze było funkcjonowanie we wsi więcej niż jednego młyna [...]". Więcej zob. M. Kamler Folwark szlachecki, s. 110-111.

73 KDW, t. 6, nr 182: „[...] ipse Wylhelmus et sui successores cum nostro et successorum nostrorum provisore per medium suis sumptibus temporibus oportunis reedificabunt, habebitque eciam domum cum area ibidem, duos mansos liberos, tercium denarium de iudicio provenientem, unum piscatorem liberum pro mensa sua, cui licitum erit piscari in aquis ad huiusmodi civitatem pertinentibus, molendinum nostrum in Antiqua Civitate simili nomine vocitata possidebit, 
z 1380 r., wystawiony został przez burgrabiego konińskiego Świętosława dla młynarza Więc$\mathrm{ka}^{74}$. Podobne zjawiska można zaobserwować w pobliskim Kole, w którym rodzina młynarzy osadzona podczas lokacji miasta w $1362 \mathrm{r}$. została obdarowana swobodą dziedziczenia zakładu przemiałowego i użytkowała go przez co najmniej trzy pokolenia ${ }^{75}$.

$\mathrm{Z}$ tych dosyć podstawowych faktów wynika, że król, a w jego imieniu starosta, ściśle kontrolował regale młyńskie będące dla monarchy pokaźnym zastrzykiem finansowym, jeżeli weźmie się pod uwagę wszystkie tenuty należące do skarbu i generowane przez nie dochody. Z drugiej strony w źródłach dosyć wyraźnie widoczny jest proces swobodnego dysponowania przez władzę zgodami na budowę kolejnych obiektów przemiałowych, które zakładano - jak w przypadku Konina - we wsiach i miastach należących do króla lub na mocy specjalnych przywilejów nadawanych przez monarchę w dużych kompleksach dóbr szlacheckich ${ }^{76}$. Zdarzały się także przypadki, w których tenutariusz lub inna osoba postawiona blisko dworu zwracały się do króla z prośbą o wykupienie części (lub całości) dochodów z obiektów przemiałowych $\mathrm{w}$ dobrach monarszych $^{77}$. Wynika $z$ tego, że nadanie prawa do zbudowania młyna lub wykupienia dochodów z niego było traktowane jako bardzo ważny i cenny dowód łaski królewskiej. Jest to jednak

ad quod molendinum arenam in loco viciniori et rubeta atque edificia pro aggere piscine et pro molendino in silva nostra excidet, conducet et ad usus molendini convertet, in piscina vero ipsius molendini pro mensa nostra pisces piscabuntur et pro nostris successoribus, quocienscunque fuerit necessarium seu opportunum".

${ }^{74}$ T. Jurek, Kilkanaście niedrukowanych, s. 108-110; KDW, t. 6, nr 268.

75 T. Związek, Testament młynarza, s. 161-163; K. Witkowski, 0 dokumencie lokacyjnym Koła, w: Królewskie miasto Koło. Studia w 650. rocznice lokacji miasta, red. I. Skierska, Koło 2012, s. 19-30.

76 AGAD, Metryka Koronna [dalej: MK], t. 20, k. 214.

77 Patrz niżej.

78 KDW, t. 2, nr 831; KDW, t. 3, nr 1581, 1761; KDW, t. 5, nr 206; KDW, t. 6, nr 122, 144, 158, 161, 182, 342; KDW, t. 9, 1260. Por. M. Dembińska, Przetwórstwo zbożowe w Polsce średniowiecznej (X-XIV wiek), Wrocław 1973, s. 219-224.

79 Leb. Stiftsreg., s. 85.

80 Tamże, s. 86: „Primo habet unum retro curiam Kazimir cum una rota; et de ista et aljis quinque sequentibus pertinet II partes ad curiam, ad molendinatorem tercia pars, ita quod lucrum est iacertum. Item habet aliud molendinum penes oppidum Kazimir sicut zagadnienie wymagające odrębnych, pogłębionych studiów.

Podobną dbałość o sprawne zarządzanie młynami widać na podstawie XIV- i XV-wiecznych dokumentów opatów lądzkich. Wystawiali oni przywileje dokładnie precyzujące powinności młynarzy, ale i ściśle określające zasięg przymusu mlewnego dla poszczególnych $\mathrm{wsi}^{78}$. Zbliżony mechanizm daje się zaobserwować $w$ inwentarzu dóbr biskupstwa lubuskiego z 1405 r., w którym lustratorzy podawali informacje dotyczące przynależności dotychczasowych obiektów młyńskich i dane o budowie nowych ${ }^{79}$. Budowanie nowych młynów - związane bezpośrednio z rozwojem osadnictwa w dobrach biskupich - miało generować coraz większe dochody płynące do skarbca kościelnego ${ }^{80}$. Wzmiankowane w źródle młyny znajdowały się w większości na rzece zwanej dziś Biskupią Strugą i stanowiły w drugiej połowie XVI w. podstawę ekonomiczną majątków szlachty konińskiej, która przejęła w ciagu tego stulecia klucz kazimierski ${ }^{81}$.

Kolejnym przykładem są dzieje dóbr związanych z rodziną Brudzewskich herbu Pomian, a konkretnie z Jarandem z Brudzewa (zm. 1452), jego synem Mikołajem (zm. 1494) i wnukiem Janem Jarandem (zm. 1532), dla których głównym ośrodkami rodowymi były Brudzew położony $\mathrm{w}$ powiecie konińskim i Staw w powiecie kaliskim ${ }^{82}$. Ród od początku

itur versus Nevestow eciam cum una rota. Item est aliud molendinum penes Nevestow cum una rota. Item est aliud molendinum in villa Nevestow scilicet in secundo Nevestow et habet solum unam rotam. Item est aliud molendinum penes Kaminitza quasi in metis Kazimir et Kaminitza. Item ego locavi de novo unum molendinum construendum per Prochonem scultetum in Kamenitza et istud debet construi penes lacum sicut Gplenitza cadit ad lacum, et Procho debet habere libertatem a festo Michaelis [...] ad quinque annos tunc debet solvere duas partes et tercia debet sibi retinere iuxta consuetudinem usualem et istud est edificatum et libertas expiravit. Nota quod molendina important circa VI maldrata".

81 Por. z rejestrami poborowymi z tego okresu: ASK I 12, k. 609 (1576 r.); ASK I 13, k. 157v (1577 r.); ASK I 3, k. 604 (1578 r.); ASK I 11, s. 1381 (1583 r.)

82 K. Piotrowicz, Brudzewski Jarand, zw. Jarandem z Grabi lub Brudzewa (ur. ok. 1380, † ok. 1450), PSB, t. 3, red. W. Konopczyński i in., Kraków 1937, s. 6-8; W. Pociecha, Brudzewski Jan Jarand, h. Pomian († 1532), PSB, t. 3, s. 5-6; Z. Górczak, Kariery majątkowe rodzin aspirujących do kręgu elity możnowładztwa wielkopolskiego $w$ drugiej połowie XV i początkach XVI w., Poznań 2013, s. 42-82. 
stał blisko dynastii rządzącej i wspierał Jagiellonów (w szczególności Władysława Jagiełłę i Kazimierza Jagiellończyka), którzy nie szczędzili panom z Brudzewa licznych nadań ziemskich i urzędniczych. Największy rozwój majątku tej rodziny nastąpił za życia Mikołaja z Brudzewa i jego syna Jana Jaranda, którzy prowadzili dosyć aktywną politykę handlowania wsiami ${ }^{83}$.

$\mathrm{Z}$ punktu widzenia prezentowanego tematu istotne znaczenie mają dwa aspekty związane z działalnością panów z Brudzewa. Otóż przyglądając się dokładniej ich poczynaniom, widać ogromne zainteresowanie rozrostem dóbr, w które obydwaj możnowładcy inwestowali niemałe pieniądze ${ }^{84}$. $Z$ drugiej strony na podstawie materiału z ksiag ziemskich obserwuje się zaangażowanie obydwu panów $\mathrm{w}$ obrót ziemią i kumulowanie najlepszych - z ekonomicznego punktu widzenia - wsi, skupionych wokół Brudzewa i Stawu. Aspiracje w gospodarczej dominacji w regionie widoczne są także w jednym $\mathrm{z}$ aktów włączonych do Metryki Koronnej na początku XVI w. ${ }^{85}$ Tekst ten został wprowadzony do księgi w 1512 r. przez Jana Jaranda, o czym świadczy tytuł wpisu: Maiestas Regia confirmat theloneum in vadis, rippis fluviorum Kyelbaszka magnifici Joannis Jarandi de Brudzowo palatini Lanciciensis ${ }^{86}$. Akt ten potwierdzać miał przekazanie przez Władysława Jagiełłę w 1429 r. Jarandowi z Grabi (Brudzewa) prawa do pobierania opłat $\mathrm{w}$ wysokości pół grosza od każdego pieszego i konnego na mostach oraz groblach w okolicach Brudzewa na rzekach Kiełbasce i jej prawdopodobnym

83 Z. Górczak, Kariery majątkowe, s. 390-394.

84 Zbyszko Gróczak policzył, że Mikołaj z Brudzewa (razem ze swoimi braćmi) od ok. 1450 do 1488 r. zainwestował 3606 grzywien i 1540 florenów, natomiast jego syn Jan Jarand w latach 1493-1530 kwotę rzędu 2874 grzywien i 2650 florenów. Zob. Z. Górczak, Kariery majątkowe, s. 395-397.

85 KDW, t. 9 , nr 1206

86 Tamże.

87 Tamże: „[...] noticiam habituris quomodo attendentes dampna et plurima incommoda subditorum nostrorum, que eisdem in vadis et rippis fluviorum Kyelbasska in herediatate Russkowo et Vanthka, in hereditate Policze et fluvium fluentem inter oppidum Brudzow et villam Czaple dictam [...]". Zob. E. Wolnicz-Pawłowska, Nazwy wodne, s. 217-218.

88 KDW, t. 9, nr 1206: „[...] magnifico Jarando de Grabye palatino predicto, ut ipse et ipsius posteri in dictis hereditatibus suis in flumini- dopływie zwanym Wędką (Vanthka) ${ }^{87}$. Monarcha miał także zobowiązywać możnowładcę i jego potomków do regularnego dbania o stan przepraw $^{88}$. Wydawcy Kodeksu dyplomatycznego Wielkopolski uznali analizowany dokument za fałszerstwo na podstawie błędnej listy świadków, gdzie występowały także postaci fikcyjne, jak chociażby podkomorzy kaliski Maciej z Głuchowa ${ }^{89}$. Niezależnie od tego przytoczony dokument może być traktowany jako doskonałe świadectwo działań panów na Brudzewie, którzy w swoich aspiracjach dążyli do kumulacji dóbr wokół swojej głównej siedziby rodowej, w której pobliżu w późnym średniowieczu funkcjonowało 7 młynów wodnych. Tak intensywny rozwój władztwa panów na Brudzewie wynikał nie tylko z bieżących dochodów, musiał być też zasilany przez inne źródła. Doskonałą okazją do zdobycia dodatkowych funduszy było nie tylko intratne małżeństwo Jana Jaranda z Katarzyną z Górków, ale także objęcie stanowiska starosty brzeskiego w latach $50 . \mathrm{XV}$ w. przez jego ojca Mikołaja, który pod koniec życia zarządzał także starostwami piotrkowskim i wieluńskim ${ }^{90}$. Rabunkowa polityka prowadzona w królewszczyznach przez Brudzewskiego została potwierdzona $\mathrm{w}$ inwentarzu brzeskim z 1494 r., gdzie podczas szczegółowej lustracji zanotowano bardzo złą kondycję zamku i okolicznych folwarków ${ }^{11}$. Stan ogólnej ruiny (,in castro omnia sunt ruinosa”) przyczynił się zapewne do odebrania przez Jana Olbrachta tenuty i popadnięcia Mikołaja Brudzewskiego w niełaskę monarchy ${ }^{92}$.

bus et fluviis per predictas hereditates fluentibus et in aliis locis transeuntibus nocivis pontes et aggeres et alia quovis ob tacula edificet et construat, emendet, ut ipsi subditi nostri et alii homines per dictas hereditates, flumina et fluvios, cum eorum rebus et mercanciis, libere sine quovis dampno equitent et vadant".

89 Tamże, przyp. 14

90 Z. Górczak, Kariery majątkowe, s. 66, 78-79; Inwentarz dóbr starostwa brzeskiego na Kujawach z roku 1494, wyd. W. Posadzy i A. Kowalewicz, „Studia i Materiały do Dziejów Wielkopolski i Pomorza", 2, 1956, s. 359-362.

91 Inwentarz dóbr, s. 396-398.

92 Tamże, s. 397; Z. Górczak, Kariery majątkowe, s. 66-67. Polityka ta nie powinna dziwić w omawianym okresie, gdyż podobne działania obserwowane są w części dóbr starościńskich arcybiskupstwa gnieźnieńskiego za pontyfikatu Jana Łaskiego, który obsadzał je bliskimi krewnymi. Za tę informację dziękuję mgr. Michałowi Słomskiemu. 
Niestety w dostępnym materiale nie udało się odnaleźć tekstów ewidentnie świadczących o inwestowaniu panów na Brudzewie w przemysł młyński. Wszystkie obserwacje dotychczas poczynione opierały się - w głównej mierze na pośrednich danych. Warto jednak odnotować, że w księgach Metryki Koronnej zachował się tekst przywileju wydanego przez Aleksandra Jagiellończyka Janowi Jarandowi z Brudzewa, przyznający mu prawo do wykupu $1 / 3$ dochodów z młyna od młynarza Michała zwanego Narożnym („Naroschni vocati”) za 50 grzywien; nadanie królewskie miało charakter dożywotni ${ }^{93}$. W tych samych kategoriach opartych na faworyzowaniu bliskich współpracowników i czasochłonnym procesie budowy rodzinnej fortuny należałoby postrzegać zaangażowanie rodziny $\mathrm{w}$ pobór podatków pokoszyckich za rządów Kazimierza IV Jagiellończyka. Dane pochodzące z Metryki Koronnej jasno pokazują, że Brudzewscy byli głównymi osobami kontrolującymi pobór podatków z ziemi brzeskiej $^{94}$. Było to oczywiście jedno z potencjalnych źródeł dochodu, ale na pewno stanowiło pokaźny zastrzyk finansowy, który zapewne w jakimś stopniu inwestowano także w rozwój przemysłu młynarskiego.

Jak wspomniano już wcześniej, niemożliwe jest uchwycenie wszystkich źródeł badanego okresu i tym bardziej ustalenie, w jaki sposób Brudzewscy herbu Pomian wpływali na rozwój swoich dóbr w skali mikro. Nie znamy żadnych umów między nimi a chociażby kmieciami czy młynarzami, nie wiemy też, jak wyglądał dokładny inwentarz wsi należących do tego rodu. Mimo tych ogromnych braków widać bardzo dokładnie, że obiekty przemiałowe znajdujące się w dobrach tej szlacheckiej rodziny były

\footnotetext{
93 MK, t. 20, k. 214.

94 Zob. np.: MK, t. 12, k. 46, 111, 163, 228, 232. Por. Matricularum Regni Poloniae Summaria, wyd. T. Wierzbowski, t. 1, Warszawa 1905 , nr 737, 916, 1125, 1363, 1374.

95 0. Strumieński, 0 sprawie, sypaniu, wymierzaniu i rybieniu stawów, wyd. F. Kucharzewski, Kraków 1897, s. 26-27.

96 Tamże, s. 34.

97 Wielkopolskie roty sądowe XIV-XV wieku [dalej: WRS], t. 1 (roty poznańskie), t. 2 (roty pyzdrskie), t. 3 (roty kościańskie), t. 4 (roty kaliskie), t. 5 (roty gnieźnieńskie), oprac. H. Kowalewicz, W. Kuraszkiewicz, Warszawa 1959-1981. WRS, roty kaliskie, nr 1056,
}

starannie zarządzane, a przemysł młyński stanowił jedną z podstaw bytu ekonomicznego panów na Brudzewie.

\section{Problemy życia codziennego}

Młyn jako obiekt przemysłowy średniowiecza i epoki nowożytnej, funkcjonujący $\mathrm{w}$ przestrzeni sąsiedzkiej, był także powodem zagrożenia dla okolicznych mieszkańców, którzy wielokrotnie musieli radzić sobie ze skutkami podtopień powodowanych przerwanymi groblami. Olbrycht Strumieński w swoim poradniku włościańskim zauważył, że słaba konstrukcja grobli często prowadziła do podmywania wałów, które z czasem przerywały się ${ }^{95}$. Ostrzegał także, że „nie dobra rzecz jest mlyn na stawie budować, a zwłaszcza w pośrzodku groblej. Abowiem nie dobrze obwarujesz wzięcia wody na młyn z stawa, barzo się rady na tych młyniech stawy rwą; abowiem nie może być bez tego, by się i grobla nie miała trząść, kiedy młyn miele, i ty koryta, którymi woda idzie na koła, muszą się w groblej ruszyć" ${ }^{\prime}$. Zabiegi mające na celu powiększanie wysokości grobli nazywano podnoszeniem grobli ${ }^{97}$ lub koła $^{98}$; praktyka ta sprowadzała się w rzeczywistości nie tylko do zwiększania spadu wody na koło, ale - co ważniejsze - do zwiększania pojemności stawów młyńskich, dzięki czemu wydłużała się praca kół młyńskich i tym samym ilość przerobionego zboża, co naturalnie przekładało się na większy zarobek. Co ciekawe, tego typu praktyki musiały być na tyle poważne i zarazem powszechne, że powoływano komisje, które sprawdzały z ramienia sądu, czy wysokość konstruowanych grobli nie była większa od powszechnie ustanowionej. Warto przy tym zaznaczyć, że przypadki

s. 471-472: „Tako mi pomoży Bóg i święty krzyż, jako to świadczę, iże pan Jan Zawidowski swym podniesieniem grobiej nad starą grobia [a] nie zatopił młyna księdzu Janowi Lutkowi; tą grobią, [t]co młyn na Brzeziu maja”. Por. KsWiej I, nr 4579: „Gdim theda poczel najlepyey mlecz, przerwala mi szię grobla, thak yzem thilko pol roka myel, bo gdim zassią zastavil, thedim poczal mlecz [...]".

98 WRS, roty poznańskie, nr 1238, s. 442-443: „Tako ijm etc., jako Przechna nie podniosła koła u młyna w Zielonej Dąbrowie wyszej, niźli jako młynarze królewscy s sądu dani ustawili, jako też przysądny list pośledni mowi". 
samowoli budowlanej zdarzały się bardzo często i nie zawsze powodowały zamierzony skutek, co potwierdza zapiska z 1428 r.: „,...] tako nam etc., jako to świadczą, jako ksiądz Maciej Dryja, pan Ścibor i Wojciech zachowali i jęli wodę wyszej niż jednacze z prawa dani znamię ustanowili, i tym zachowanim wody młyn Radzichę księdza dziekana, łąki, olsze, sadzawkę i jinne użytki księdza dziekanowy [woda] zatopiła i uszkodziła" 99 .

Sąsiedztwo młynów wodnych nie było korzystne dla wiejskich społeczności i dlatego niejednokrotnie młynarzy i właścicieli młynów automatycznie oskarżano o katastrofy hydrologiczne, których finał bardzo często miał miejsce w sądzie: „Jako to świdczę, iże ksiądz Mikołaj skolastyk nie podniosł mi łana [i] pogrodek u młyna w Trojanowie za jego dzierżenia wyszej, i nie zatopił młyna Wojnowo"100; „Tako nam pomoży Bog i święty $\dagger$, jako coż pan Łukasz uczynił młyn na Krzynkach, [nie podniosł] tym podniesieniem wody ziemia przed pogrodkami ani pod pogrodkami, ani jemu szkody uczynił w ogrodziech, w stodołach, w łąkach, w pastwiskach, a nie w lecie tym podniesieniem wody" ${ }^{101}$. $\mathrm{Z}$ tego też powodu nie można się dziwić temu, że młyny były wielokrotnie napadane lub palone, a młynarzy przepędzano ${ }^{102}$. Z jednej strony zapewne trzeba pamiętać o chęci odpłacenia za problemy natury ekonomicznej, z drugiej natomiast należy zdawać sobie sprawę z tego, że młyna-

99 Tamże, roty kaliskie, nr 725, s. 330-331.

100 Tamże, roty poznańskie, nr 1444, s. 507-508.

101 Tamże, roty pyzdrskie, nr 1109, s. 481-482.

102 Tamże, roty kaliskie, nr 674, s. 308: „Jako to świadczą, jako Michał z Więceńcem nie wygnali gwałtem młynarza Wirzbięcinego z jego młyna".

103 Tamże, roty kaliskie, nr 307, s. 160: „Jako to świadczymy, jako Jarant posłał do pana Jurkowa młyna dziesięć towarzyszow gwałtem i wzięli mu wieprze i żyto w jego dzierżeniu"; tamże, roty poznańskie, nr 339, s. 126: „Jako Jaszek przyjał w mą dzierżewę (!) samotrzeć tako z dobrymi jako sam a se stem kmiot i szedł gwałtem mocą do mego młyna i wziął mego człowieka i żelaza. Item Jasco iurabit: Co człowiek zabit pana Więceńcew, to nie s mą wolą ani radą"; tamże, roty poznańskie, nr 1537, s. 543-544: „Tako jim Bog pomoż †. Jako to świadczymy, iże pan Wociech Spławski nie wziął we młynie w Kobylem Polu dwunacie ćwierciej maki paniej Dorotyjej w jej połowicy młyna, cso by na nię słuchało, gwałtem mocą, w sześci sobie rownych a w dziesiąci podlejszych". Por. z materiałem mazowieckim: Zapiski i roty polskie XV-XVI wieku z ksiąg sądowych ziemi war- rze (jako grupa społeczna) byli dość zamożni, a w ich gospodarstwach znajdował się niemały majątek, który w łatwy sposób mógł zmienić właściciela.

Materiał sądowy notuje nie tylko napady na młyny, w których rabowano ${ }^{103}$, raniono ${ }^{104}$ czy wyganiano młynarzy ${ }^{105}$. Niekiedy udaje się odnaleźć obszerniejsze relacje, które dokładnie opisują XV-wieczne kłótnie o obiekty przemiałowe w Królestwie Polskim. Wśród rot sądowych poznańskich zachowała się cała wymiana zdań, jaka miała miejsce podczas średniowiecznego procesu z $1434 \mathrm{r}^{106}$

W źródle czytamy, że „item veniens Johannes loco ministerialis Poznaniensis coram iudicio recognovit, prout fuit datus ad visionem alias Nawÿdzenye, quem dominus Petrus Scora subiudex Poznaniensis receperat pro eo, prout super ipsum dominus Dobrogostius Colenssky castellanus Kamÿniensis proposuerat in iudicio alias Ozalowal ex parte nobilis Sandiwog̈ Nyewyersky pro destruccione molendini et expulsione molendinatoris alias Ozrambj̈enjemlÿna [...]". Konflikt toczył się o zniszczenie młyna nad jeziorem w miejscowości Michocin (Mÿchoczÿn) położonym w powiecie poznańskim ${ }^{107}$. Oskarżonym był podsędek poznański Piotr Skóra (Scora) piszący się z Gaju i Kiączyna $^{108}$, natomiast oskarżycielem w imieniu pokrzywdzonego Sędziwoja Niewierskiego był kasztelan kamieński Dobrogost Koleński. $\mathrm{Z}$ zapisek widać, że sprawa była na tyle poważ-

Szawskiej, oprac. W. Kuraszkiewicz, A. Wolff, Kraków 1950, nr 951 1065, 2948, 2563.

104 WRS, roty kościańskie, nr 1102, s. 484: „Jako to świadczą, jako Jędrzych Karchowski nie ranił Jana, syna Młynarzewego, ani mu dał trzech ran krwawych, ani jich ot niego ma".

105 Tamże, roty pyzdrskie, nr 567, s. 285: „Rotha procedentis induccionis: Tako jim etc., jako o tem wiedzą, jako pani Margorzata Kobylińska nie segnała młynarza s Konińskiego młyna, ku któremu też Więceńc prawo ma”; tamże, roty kaliskie, nr 623, s. 287: „Tako ijm etc., jako to świadczę, jako wygnaniu młynarzewemu z młyna Zawidowskiego minęły trzy lata i zgorzeniu tego jistego młyna"; tamże, roty kaliskie, nr 647, s. 308: „Jako to świadczą, jako Michał z Więceńcem nie wygnali gwałtem młynarza Wirzbięcinego z jego młyna".

106 Tamże, roty poznańskie, nr 1577, s. 559-564.

107 Michocin (http://www.Slownik.ihpan.edu.pl/search.php?id=20614,http:// www.slownik.ihpan.edu.pl/search.php?id=20615, dostęp: 09.08.2013)

108 Urzędnicy dawnej Rzeczpospolitej XII-XVIII wieku. Spisy, red. A. Gąsiorowski, t. 1, z. 1, oprac. M. Bielińska, A. Gąsiorowski, J. Łojko, Wrocław-Warszawa-Kraków 1985, s. 150. 
na, iż zdecydowano się na wizję lokalną, gdzie $\mathrm{w}$ miejsce spalonego młyna zaprowadzono woźnego sądowego Jana (,et dum ministerialem ibi adduxit") i pokazano mu zniszczenia obiektu przemiałowego (,Ministerialis! Ecce vides hic est agger alias Groblja. Hic dominus [Piotr Skóra - T.Z.] voluit videre ubi molendinum destrueret alias Sekl et molendinatorem repelleret alias $Z a$ gnal albo Mlÿnarczj̈ka"). Podsędek bronił się przed oskarżeniami kasztelana, zaprzeczając istnieniu jakichkolwiek pozostałości po młynie w postaci wałów, drewnianej podstawy budynku (podu) i podgrodki (,et dominus subiudex dixit ministeriali: Ministerialis! Vides, quia hic non est destruccio molendini alias Skazamlïna. Nÿe

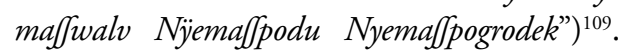
Ciekawe jest to, że Dobrogost (mimo roli oskarżyciela) uznawał zasadę domniemania niewinności, co wyraźnie widać w jego wypowiedzi, w której przyjmował relację pokrzywdzonego, ale zdawał sobie także sprawę z faktu, że młyny bardzo często płonęły w wyniku zdarzeń losowych („Ibi tunc dominus Colenssky dixit: Ministerialis! Quomodo istam destruccionem vellem aprobare alias Tanjkaza vkazacz, quia ista

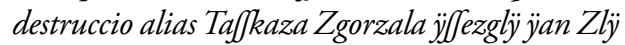
ludze abo pozarem zgorzata"). Wypierającego się winy Piotra Skórę pogrążył jednak dowód odnalezienia części koła młyńskiego w okolicy spornego terenu: „Et hoc procurator Sandiwogii Nyewyerssky dixit, et quando transiverunt per scopulos alias pokopczech et quando fuit penes lacum alias kÿedj byto podle ÿeziora nakopczv thedj̈ Wÿrzuczono zwono kola mlÿnskÿego. Ibi dominus Colensky dixit ministeriali: Ministerialis! Ecce videns, quia adhuc signum rothe molendini alias Othocz yeffcze znamÿan kola mlÿna. Et dominus subiudex dixit ministeriali: Non hic fuit molendinum, sed alias ondze".

Nie wiemy, jak zakończył się spór z 1434 r. i kto go wygrał. Wiadomo natomiast, że przyczyną tego konfliktu była sprawa granic pomiędzy posiadłościami dwóch szlachciców, co

109 Podgrodka była drewnianym urządzeniem doprowadzającym wodę na koło młyńskie. Zob. Podgrodka, w: Stownik polszczyzny XVI wieku, t. 25, Warszawa 1997, s. 431; Pod, w: Stownik polszczyzny, s. 326 . oczywiście sugeruje, by wpisać to zachowanie w klimat epoki staropolskiej. Warto jednak zauważyć, że proces Niewierskiego i Skóry pozwala na zrozumienie znaczenia takich wydarzeń na rozwój sieci młyńskiej w średniowieczu i nowożytności. Dobrogost z Kolna, oskarżając podsędka poznańskiego, mówił o tym, że młyn został być może zniszczony przez niego - a raczej bandę „złych ludzi” - jednak równie dobrze mógł spłonąć samoczynnie. Należy pamiętać, że młyn był w epoce staropolskiej pewnego rodzaju fabryka, miejscem niezwykle zaawansowanym technicznie, dającym ogromne dochody jego właścicielowi. To zrozumiałe, że obiekty takie musiały ze sobą konkurować i próbować pozyskiwać coraz to nowych klientów, dlatego też w pełni można zaakceptować, że niektóre instytucje (takie jak choćby klasztor w Lądzie) mocno pilnowały przestrzegania regale młynnego. W związku z tym szlacheckie najazdy na młyny można zapewne tłumaczyć po części jako reakcję na brak ustalonych linii podziału przemiału zboża we wsiach danego terytorium i chęć szybkiego dorobienia się.

Analizując materiał źródłowy pochodzący z późnego średniowiecza, jesteśmy w stanie mniej lub bardziej precyzyjnie zrekonstruować przyczyny przywoływanego wcześniej konfliktu o zgorzały młyn. Jego początki można datować na lata 1410-1434, kiedy to właścicielem wsi Niewierz był Bodzęta, ojciec Sędziwoja, który w ciągu swojego życia po przejęciu władztwa w dobrach dokonał samowolnej zmiany granic w okolicach jeziora michocińskiego i wsi do niego przylegającej. W tym czasie musiał zapewne zostać wybudowany młyn, pełniący nie tylko funkcje gospodarcze, ale także będący istotnym obiektem wyznaczającym granicę dóbr rodziny Niewierskich. W latach 1434-1435 miały miejsce także inne konflikty sądowe z Piotrem Skórą, między innymi o kopce graniczne, nielegalny połów ryb o wartości pięciu grzywien czy wcześniej wzmiankowane spalenie mlyna wodnego. Te skromne, jednak dosyć istotne dane pozwalają postawić tezę, że celem oskarżonego podsędka poznańskiego nie było przede wszystkim nisz- 
czenie zaplecza gospodarczego Niewierskich, a jedynie usiłowanie uregulowania $\mathrm{z}$ nimi spornej granicy.

\section{Zakończenie}

Tematyka gospodarki wiejskiej w okresie średniowiecza i wczesnej nowożytności jest cały czas ważnym polem do badań gospodarczych i społecznych. Warto przy tym pamiętać, że jest to także dziedzina wymagająca bardzo rozległych kwerend źródłowych, głównie w księgach sądowych grodzkich i ziemskich, których objętość przyrastała z znacząco z każdym dziesięcioleciem badanego okresu. Dwieście pięćdziesiąt lat kształtowania sieci młynów wodnych w przestrzeni ekonomicznej określonego terytorium jest także czasem wielu zmian nie tylko w strukturze gospodarczej, ale także politycznej i społecznej. Pewna część problemów nie mogła zostać wyjaśniona ani nawet częściowo przeanalizowana w prezentowanym artykule, gdyż dotyka tematyki wymagającej zupełnie osobnych i pracochłonnych badań.

Jednym z takich zagadnień jest sprawa dystrybuowania prawa do budowy obiektów przemiałowych wydawanych przez władzę świecką danej dzielnicy lub - w późniejszym okresie monarchę. Niestety do tej pory nie wiadomo dokładnie, w jaki sposób król w XIV i XV w. dysponował prawem udzielania pozwoleń na budowę zakładów przemiałowych; trudno stwierdzić także, jak w tych relacjach odnajdywało się średnie rycerstwo i szlachta, które - co jasno pokazuje materiał ksiag sądowych - bardzo często wpływało na liczbę obiektów przemiałowych poprzez ich grabież i świadome burzenie. Co jeszcze istotniejsze, nie wiadomo, czy monarcha karał szlachtę lub duchowieństwo za założenie młyna bez jego zgody. Zagadką pozostaje także do tej pory - pomimo tekstu Karola Buczka - funkcjonowanie regale młynnego w późnym średniowieczu ${ }^{110}$. Niezbędne jest głębsze spojrzenie na tematykę powstawania przemysłu młyńskiego w czasach kolonizacji na prawie niemieckim na ziemiach polskich i dokładne przeanalizowanie dostępnych przywilejów, które jako jedyne mogą dostarczyć informacji na temat tego złożonego procesu.
Zupełnie odrębną kwestią jest ustabilizowanie się sieci młynów wodnych i wiatraków - to znaczy takie nasycenie obiektami przemiałowymi, które zaspokajałoby potrzeby powolnie, acz konsekwentnie rozwijającego się społeczeństwa XIV-XVI w. Z badań przeprowadzonych wyżej dla jednego powiatu wynika, że stabilizacji takiej można szukać w dwóch przedziałach czasowych. Pierwszy przypadał na drugą lub trzecią dekadę XVI w., kiedy liczba obiektów przemiałowych na przebadanym terenie nie zmieniła się znacząco od tej zrekonstruowanej dla schyłku średniowiecza; drugi natomiast - na ostatnie dekady tego samego wieku, kiedy to - zgodnie z wyliczeniami Marcina Kamlera - rozwój przemysłu osiagnął stabilizację, zniszczoną $\mathrm{w}$ dosyć drastyczny sposób dopiero przez potop szwedzki ${ }^{111}$. W związku z powyższym można uznać - jak na razie w formie roboczej tezy - że znaczący postęp w budowaniu coraz to nowych młynów i wiatraków nastąpił w Polsce w wieku XIV, poł. XVI i około lat 80.-90. tego stulecia. Momenty te należałoby wiązać z intensywnymi przeobrażeniami społeczno-gospodarczymi na ziemiach polskich, wspomnianą wcześniej kolonizacją, skutecznym rozwojem osadnictwa w kraju i ogólnie dobrą koniunkturą gospodarczą związaną chociażby z rozwojem folwarku szlacheckiego.

Wnioski dotyczące XV stulecia należy wyciągać bardzo ostrożnie, ponieważ materiał ksiąg sądowych dawnego województwa kaliskiego jest w tej mierze zwodniczy i słabo przebadany ${ }^{112}$. Takie obserwacje należałoby przeprowadzić w oparciu o materiał małopolski, dla którego istnieją zaawansowane prace słownikowe, bardzo dobre indeksy ksiąg sądowych pochodzące z XVIII w., ale także Liber beneffciorum Jana Długosza, które w tym względzie należałoby zestawić $\mathrm{z}$ danymi skarbowymi z XV i XVI w. ${ }^{113}$ Takie studium mogłoby pełniej opisać gospodarczy rozwój $\mathrm{XV}$-wiecznego

\footnotetext{
110 K. Buczek, Z dziejów mtynarstwa, passim.

111 M. Kamler, Folwark szlachecki, s. 111.

112 Por. z mapą Sieć młynów wodnych w powiecie konińskim (13001550), s. 109.

113 Niestety całkowitej weryfikacji należałoby poddać artykuł Zofii Podwińskiej o młynach wodnych w Małopolsce u schyłku średniowiecza: Z. Podwińska, Rozmieszczenie wodnych.
} 
młynarstwa i wskazać momenty stabilizacji i rozkwitu tego przemysłu.

Przedstawiony artykuł od początku nie rościł sobie prawa do wyczerpania tematu. Jest on próbą opisania zjawiska, którego korzenie - odnośnie do ziem polskich - tkwią głęboko w XIII i XIV w. i które powinno zostać przebadane gruntownie nie tylko przez historyków, ale także archeologów i geografów różnych spe-

\section{Literatura}

Źródła rękopiśmienne i niepublikowane:

Archiwum Główne Akt Dawnych (AGAD): rejestry poboru nadzwyczajnego dotyczace powiatu konińskiego. Dział: Archiwum Skarbu Koronnego, oddział I, księgi 3, 5, 11-13; Metryka Koronna, t. 12, 20.

Najstarsza ksiega ziemska koniniska (13941416), oprac. T. Gidaszewski. Materiał w rę-

Źródła drukowane:

Inwentarz dóbr starostwa brzeskiego na Kujawach z roku 1494, wyd. W. Posadzy, A. Kowalewicz, „Studia i Materiały do Dziejów Wielkopolski i Pomorza”, 2, 1956, s. 359-393.

Joannis de Lasco liber beneficiorum, wyd. J. Łukowski, t. 1-2, Gniezno 1880-1881.

Jurek T., Kilkanaście niedrukowanych dotad dokumentów wielkopolskich, w: Fontes et historia. Prace dedykowane Antoniemu Gasiorowskiemu, Poznań 2007, s. 108-110.

Knigi polskoj koronnoj mietriki XV stoletija, wyd. T. Wierzbowski, Warszawa 1914.

Kodeks dyplomatyczny Wielkopolski, t. 2-11, red. I. Zakrzewski i in., Poznań 1878-1999.

Ksieggi sadowe wiejskie, t. 1, wyd. B. Ulanowski, Kraków 1921.

Das Lebuser Stiftsregister von 1405, hrsg. H. Ludat, Wiesbaden 1965.

Lustracja województw wielkopolskich i kujawskich 1564-1565, cz. 1-2, wyd. A. Tomczak, C. Ohryzko-Włodarska, J. Włodarczyk, Bydgoszcz 1961-1963.

\section{Źródła kartograficzne:}

Gilly D. von, Special Karte von Sudpreussen mit allerhoechster Erlaubniss aus der königlichen cjalności. Na pewno warto w dalszych analizach poświęconych tej tematyce przyjrzeć się dokładniej zależności początków osadnictwa i akcji prawnych towarzyszących budowie wsi, miast i młynów. Jest to oczywiście zadanie złożone, które powinno być wspierane badawczo przez nowoczesne technologie komputerowe z zakresu Systemów Informacji Geograficznej (GIS) oraz rozszerzone o badania onomastyczne.

kopisie znajduje się w Pracowni Słownika Historyczno-Geograficznego Wielkopolski w średniowieczu w Poznaniu.

Polonia Maior Fontes, oprac. J. Łojko. Pełna baza danych dostępna w Bibliotece Miejskiej w Koninie.

Lustracje i inwentarze dóbr królewskich powiatu konińskiego z XVI-XVIII wieku. Cześś 1: lata 1511-1559, wyd. P. Dembiński, A. Nowak, „Rocznik Koniński”, 13, 1999.

Strumieński O., O sprawie, sypaniu, wymierzaniu i rybieniu stawów, wyd. F. Kucharzewski, Kraków 1897.

Teki Dworzaczka. Materiaty historyczno-genealogiczne do dziejów szlachty wielkopolskiej $X V-X X$ wieku (http://teki.bkpan.poznan.pl/, dostęp: 28.08.2013).

Volumina Constitutionum, wyd. S. Grodziski, I. Dwornicka, W. Uruszczak, t. 1-2, Warszawa 1996-2005.

Volumina Legum, t. 1-2, wyd. O. Jozafat, Petersburg 1859.

Wielkopolskie roty sadowe XIV-XV wieku, t. 1-5, oprac. H. Kowalewicz, W. Kuraszkiewicz, Warszawa 1959-1981.

Zapiski $i$ roty polskie XV-XVI wieku z ksiag sadowych ziemi warszawskiej, oprac. W. Kuraszkiewicz, A. Wolff, Kraków 1950.

grossen topographischen Vermessungs-Karte, skala 1:150 000, Berlin 1802-1803. 
Mapa Taktyczna Polski, Wojskowy Instytut Geograficzny, skala 1:100 000, Warszawa

Literatura przedmiotu:

Bartoszewicz A., Piśmienność mieszczańska w późnośredniowiecznej Polsce, Warszawa 2012.

Berman C.H., Southern French Cistercian Water Mills, „International Molinology”, 85, 2012, s. 8-13.

Boroda K., Kmieć, tan czy profit? Co byto podstawa poboru tanowego w XV i XVI wieku?, $\mathrm{w}$ : Cztowiek wobec miar i czasu w przesztości, red. P. Guzowski, M. Liedke, Kraków 2007, s. $152-170$.

Boroda K., Rynek produkcji piwa i handlu alkoholem w woj. tęczyckim w XVI wieku, w: Rynki lokalne $i$ regionalne $w X V-X V I I I$ wieku, red. P. Guzowski, K. Boroda, Białystok-Kraków 2013, s. 55-85.

Brady N., Mills in Medieval Ireland: Looking Beyond Design, w: Wind \& Water in the Middle Ages: Fluid Technologies from Antiquity to the Renaissance, red. S.A. Walton, Tempe 2006, s. 39-63.

Brykała D., Rekonstrukcja retencji zbiornikowej zlewni Skrwy Lewej w ciagu ostatnich 200 lat, „Przegląd Geograficzny”, 71 (1), 2005 , s. 69-89.

Buczek K., $Z$ dziejów mtynarstwa $w$ Polsce średniowiecznej, „Studia Historyczne”, 12 (1), 1969, s. 17-52.

Chłapowski K., Written sources, w: Historical Atlas of Poland in the 2nd half of the 16th century. Voivodeships of Cracow, Sandomierz, Lublin, Sieradz, Eęczyca, Rawa, Ptock and Mazovia, ed. M. Słoń, vol. 2, Frankfurt am Main-Berlin-Bern 2014, s. 47-61.

Civitas Conyn. Dzieje miasta i starostwa do schytku XVIII w., red. J. Łojko, t. 1, Konin 2011.

Dembińska M., Przetwórstwo zbożowe w Polsce średniowiecznej (X-XIV wiek), Wrocław 1973.

Dembińska M., , Ręczny”, ,doroczny”, czy „w pańskim ręku"? Nieco o terminologii źródet polskich, „Studia Źródłoznawcze”, 26, 1981, s. 190-192.

Deszczyńska M., Surowiecki Wawrzyniec, w: Polski Stownik Biograficzny, t. 46, z. 1, red. A. Romanowski, Kraków 2009.

Fokt K., Późnośredniowieczne osadnictwo wiejskie na Dolnym Ślasku w świetle badań archeologicznych, Kraków 2012.
1925-1939 (http://polski.mapywig.org/viewpage.php?page_id=7, dostęp 09.04.2014).

Gidaszewski T. et al., Transformations of the $\mathrm{Na}$ tural Landscapes of the Middle Notec Region form the 10th to 16th Century, w: Landscapes and Societies in Medieval Europe East of the Elbe: Interactions Between Environmental Settings and Cultural Transformations, ed. S. Kleingärtner et al., Toronto 2013, s. 245-273.

Gieysztorowa I., Źródta i szacunki w badaniach osadnictwa i demografii Polski XVI i XVII w., „Kwartalnik Historii Kultury Materialnej”, 10, 1962, s. 575-593.

Gieysztorowa I., Źródta pisane, w: Mazowsze $w$ drugiej potowie XVI w., t. 2, red. W. Pałucki, Warszawa 1973, s. 17-22 (Atlas historyczny Polski. Mapy szczegółowe XVI wieku, 7).

Gieysztorowa I., Żaboklicka A., Rejestry poborowe Mazowsza XVI w., „Kwartalnik Historii Kultury Materialnej”, 3, 1955, s. 338-355.

Gołaski J., Atlas rozmieszczenia mtynów wodnych $w$ dorzeczach Warty, Brdy i cześci Baryczy $w$ okresie 1790-1960, cz. 1-5, Poznań 1980-2006.

Górczak Z., Kariery majątkowe rodzin aspirujacych do kregu elity możnowtadztwa wielkopolskiego w drugiej potowie XV i początkach $X V I w$., Poznań 2013.

Górska K., Przyczynek do krytyki rejestrów poborowych z XVI w., „Studia Źródłoznawcze”, 1, 1957, s. 185-189.

Gregory I.N., Ell P.S., Historical GIS. Technologies, Methodologies and Scholarship, Cambridge 2007.

Guzowski P., Wptyw eksportu zboża na produkcje pszenicy i jeczmienia na rynki lokalne $w$ drugiej potowie XVI wieku, w: Rynki lokalne $i$ regionalne $w X V-X V I I I$ wieku, red. P. Guzowski, K. Borody, Białystok-Kraków 2013, s. 87-106.

Historia państwa i prawa Polski do roku 1795, t. 1, red. J. Bardach, Warszawa 1957.

Kamler M., Folwark szlachecki w Wielkopolsce w latach 1580-1655, Warszawa 1976.

Kaniecki A., Brychy D., Wptyw antropopresji na przemiany środowiska przyrodniczego $w$ średniowieczu $w$ zlewni Obry Skwierzyńskiej, w: Zmiany stosunków wodnych w czasach historycznych, red. A. Kaniecki, A. Baczyńska, Poznań 2010, s. 115-127. 
Kaniecki A., Woźniak A., Kornaś A., Wykorzystanie wód dla potrzeb mtynarskich na obszarze międzyrzecza Warty i Prosny w XVI wieku, „Przegląd Geofizyczny”, 57 (3-4), 2012, s. 379-391.

Konias A., Kartografia topograficzna państwa $i$ zaboru pruskiego od II potowy XVIII wieku do potowy XX wieku, Słupsk 2010.

Kowalczyk E., Nazwy obronne Stup, Samborza $i$ Zawada a zagadnienie obrony statej ziem polskich w średniowieczu, Warszawa 1992.

Kowalski M.D., Dzieje autografu katedralno-kolegiackiej cześsi „Liber beneficiorum diocesis Cracoviensis” Jana Dtugosza, „Studia Źródłoznawcze", 46, 2009, s. 83-94.

Krassowski B., Polska kartografia wojskowa w latach 1918-1945, Warszawa 1974.

Kubicki R., Mtynarstwo w państwie zakonu krzyżackiego w Prusach $w$ XIII-XV wieku (do 1454 r.), Gdańsk 2012.

Kubicki R., Sieć mtynów wodnych $w$ dobrach klasztornych na Pomorzu Wschodnim w XIII$X V I w$., „Hereditas Monasteriorum”, 2, 2013, s. 35-56.

Kubicki R., Wiatraki na żutawach w pierwszej potowie $X V$ wieku, „Roczniki Dziejów Społecznych i Gospodarczych", 72, 2012, s. 45-69.

Langdon J., Mills in the Medieval Economy. England 1300-1540, Oxford 2004.

Mapa gleb Polski, skala 1:300 000, red. A. Musierowicz, Warszawa 1961.

Matuszewski J., Molendinum manuale, „Studia i Materiały do Dziejów Wielkopolski i Pomorza”, 13 (25), 1979, s. 127-144.

Mączak A., Sukiennictwo wielkopolskie. XIV -XVII wiek, Warszawa 1955.

Medyńska-Gulij B., Lorek D., Pruskie mapy topograficzne dla Wielkopolski do 1803 roku, „Badania Fizjograficzne nad Polską Zachodnią", 59, 2008, s. 29-42.

Nabiałek K., Starostwo olsztyńskie od XIV do potowy XVII wieku, Kraków 2012.

Naser M., Digitale Karten zur Geschichte der Städte in Franken, Baunach 2010.

Piotrowicz K., Brudzewski Jarand, zw. Jarandem z Grabi lub Brudzewa (ur. ok. 1380, † ok. 1450), w: Polski Stownik Biograficzny, t. 3, red. W. Konopczyński i in., Kraków 1937, s. 6-7.
Pociecha W., Brudzewski Jan Jarand, h. Pomian († 1532), w: Polski Stownik Biograficzny, t. 3, red. W. Konopczyński i in., Kraków 1937, s. 5-6.

Podgórski Z., Wptyw budowy i funkcjonowania mtynów wodnych na rzeźbe terenu $i$ wody powierzchniowe Pojezierza Chetmińskiego i przylegtych cześsi dolin Wisty i Drwęcy, Torun 2004.

Podwińska Z., Rozmieszczenie wodnych mtynów zbożowych w Matopolsce w XV wieku, „Kwartalnik Historii Kultury Materialnej”, 18 (3), 1970, s. 373-402.

Reynolds T.S., Stronger than a hundred men: $A$ History of the vertical water wheel, Baltimore 2003.

Sowina U., Woda i ludzie $w$ mieście późnośredniowiecznym i wczesnonowożytnym. Ziemie polskie z Europa w tle, Warszawa 2009.

Surowiecki B., O rzekach y sptawach kraiów Xięstwa Warszawskiego, t. 1, Warszawa 1811.

Szady B., Geografia historyczna w Polsce - rozwój i perspektywy, „Studia Geohistorica”, 1, 2013, s. 19-38.

Szafran P., Inwentarze czy rejestry poborowe, „Zapiski Historyczne”, 21 (1), 1966, s. 53-71.

Wawrzyńczyk A., Gospodarstwo chtopskie w dobrach królewskich na Mazowszu w XVI i na początku XVII w., Warszawa 1962.

Witkowski K., O dokumencie lokacyjnym Kota, w: Królewskie miasto Koto. Studia w 650. rocznice lokacji miasta, red. I. Skierska, Koło 2012, s. 19-30.

Wolnicz-Pawłowska E., Nazwy wodne dorzecza Warty od źródet do ujścia Prosny, Warszawa 2006.

Worniszewski J., Król jako wtaściciel ziemski w średniowiecznej Polsce, w: Król w Polsce XIV iXV wieku, red. A. Marzec, M. Wilamowski, Kraków 2006, s. 103-135.

Wyczański A., Studia nad gospodarka starostwa korczyńskiego 1500-1660, Warszawa 1964.

Związek T., Najstarszy rejestr poboru nadzwyczajnego i szosu z 1507 roku z terenów powiatu konińskiego, „Rocznik Koniński”, 18, 2014, s. 173-201.

Związek T., Testament mtynarza z Kota. Przyczynek do badań nad późnośredniowiecznym mtynarstwem na ziemiach polskich, „Średniowiecze Polskie i Powszechne”, 5 (9), 2013, s. $155-167$. 


\title{
The formation of a network of water mills on the example of the Konin district (approx. 1300-1550)
}

\section{Summary}

The article concerns the subject which has been so far poorly studied, namely the process of the formation of a network of water mills. The studies conducted up till now have either been constructed on an uncertain source basis ( $\mathrm{Zo}$ fia Podwińska) or they have been too general to capture the small changes which could also significantly affect the increase or decline in the number of milling facilities (Rafał Kubicki). The author of the present paper made an attempt at describing detailed mechanisms governing this phenomenon on the example of the Konin district in the period of the late Middle Ages and the Early Modern Times. The source basis was provided by lists of extraordinary conscriptions,

\begin{abstract}
inventories of bishops' and royal properties, records of the lands tribunals, the diplomatic material or even supplications directed to the $16^{\text {th }}$ century chapter of Gniezno. Besides, the oaths of the lands tribunals published in Wielkopolskie roty sadowe (Court oaths in Wielkopolska region) were also fairly extensively used. The present article analyzes not only the development of a network of water mills itself but also the economic and natural factors that could have created it. Moreover, on the example of the Konin district analyses were made related to the development of properties belonging to the lords (on the example of the Brudzewski family of Pomian coat-of-arms) and royal properties.
\end{abstract}

Słowa kluczowe: Wielkopolska, średniowiecze, gospodarka, młyny wodne, starostwo, osadnictwo 15 w., osadnictwo 16 w., Konin, Koło, Ląd, Kazimierz Biskupi, wiatraki, GIS, geografia historyczna, HGIS

Keywords: Greater Poland, Middle Ages, historical economy, watermills, agrarian structures, Konin, Koło, windmills, GIS, historical geography, HGIS

mgr Tomasz Związek - asystent w Zakładzie Atlasu Historycznego w Instytucie Historii im. Tadeusza Manteuffla Polskiej Akademii Nauk. Aktywnie uczestniczy w pracach nad atlasem historycznym Wielkopolski w XVI w. oraz przygotowuje pod kierunkiem prof. Marka Stonia rozprawę doktorską poświęconą osadnictwu powiatu kaliskiego na przełomie XV i XVI w. (e-mail: tomasz.zw@gmail.com) 